Stewart, Alban

Some observations concerning the botanical conditions of the Galapagos Islands 

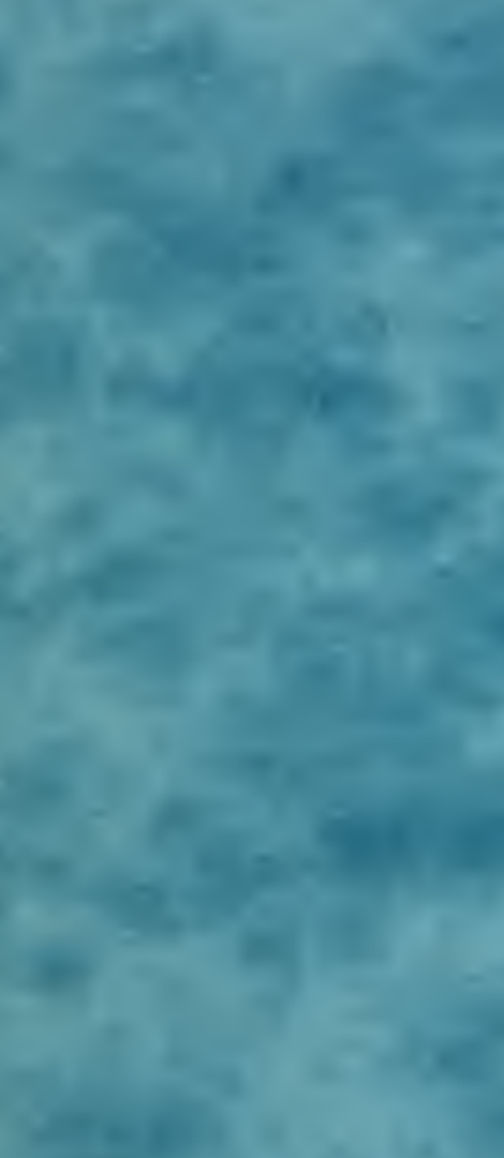




\section{SOME OBSERVATIONS CONCERNING THE BOTANICAL CONDITIONS ON THE GALAPAGOS ISLANDS.}

BY

\section{ALBAN STEWART.}

Reprinted from the Transactions of the Wisconsin academy of Sciences, Arts, and LetTers, Vol. XViII, Part I.

\section{Issued October, 1915.}




$$
\begin{aligned}
& 2 \times 252 \\
& 571
\end{aligned}
$$





\title{
SOME OBSERVATIONS CONCERNING THE BOTANICAL CONDITIONS ON THE GALAPAGOS ISLANDS.
}

\author{
By Alban SṬewart.
}

\section{INTRODUCTION.}

When I began the study and identifieation of the vascular plants of the Galapagos Islands at the Gray Herbarium, some seven ycars ago, I intended to include all of the results in a single publication. After I had eompleted that part of the work included in my paper entitled: A Botanieal Survey of the Galapagos Islands* it was found that sueh a mass of manuscript had accumulated that it would probably be better to publish this part, and to reserve the general eonsideration of the floras of the individual islands for a separate publication.

An attempt has been made in this paper to describe briefly, and in a general way, the botanical conditions as I saw them upon each of the islands visited. No attempt has been made, however, to deseribe the floras of the different islands in a detailed way, because, sueh a eonsideration would eonsume too much space, and furthermore, as our stay in some of the localities visited was very brief, there was not sufficient time available to make a sufficiently detailed study of the flora for this purpose. This is especially true in some of the larger islands, where we were obliged to get as far into the interior as possible in a short time, hurriedly collect material, with brief notes, and then start back to the shore. Expeditions into the interiors of most of the larger islands are extremely diffieult to make. Not only is the country very rough in most places, and covered with heavy vege-

- Proc. Cal. Acad. Sc1., fourth series, vol. I, pp. 7-288. 1911. 
tation, but there is also no water on the most of them; which makes it necessary for one to carry a supply of water with him. On this account it is practically impossible to make trips into the interior lasting longer than three days.

Department of Botany,

University of Wisconsin,

Madison.

\section{Abingdon Island.}

With the exception of the two small islands, Culpepper and Wenman, Abingdon is the most northern island in the group. It is located about thirteen miles northwest of Blindloe, and is the smallest one of the islands that supports an extensive mesophytic flora. This condition is brought about by the fact that it reaches an elevation of $1950 \mathrm{ft}$, and consequently it receives a greater amount of moisture than the other small islands. This island was visited during the month of September 1906. The most of the work was done on the south side where good anchorage was found for our vessel in a small bay.

The shores along the south side of the island are composed of low, lava cliffs and oceasional sand-beaches. The shores become steeper, however, towards the southwest side. On the west side there are perpendicular cliffs which rise directly from the sea to a height of over $1,000 \mathrm{ft}$. The north and east sides of the island were not visited, but judging from the appearance of these parts as seen from the vessel while sailing in the vicinity of the island, the shores are low, and the sides of the mountain are covered with lava to a considerable elevation. The lava covering the south side is mostly basaltic in character with occasional beds of voleanic cinders intermingled. This lava is of comparatively great age, and it has become stained to a redish-brown color through surface oxidation. There are extensive deposits of volcanic cinders on the southeast side of rather recent origin, the most of which have come from a small crater at an elevation of $1,000 \mathrm{ft}$. There are still slight evidences of volcanic activity around the base of this crater, as there is a constant escape of steam here, which is sometimes great enough to be seen from the shore. There is still another small einder cone on the recent lava near the shore, from which the lava in its immediate vicinity must have come. Remains of several other small craters 18-S. A. 
oecur on the old lava around an elevation of $500 \mathrm{ft}$., all of which have probably been inactive for a very long time. The lava on the south side has been thrown into ridges and folds in places, and there are also occasional lava tunnels the tops of which liave fallen in. One of these is located near the shore and is filled with sea water. The south side of the island slopes up gradually to an elevation of about $500 \mathrm{ft}$., above which the slope is steeper.

The top of the muuntain was envelloped in fog at the time it was visited so that a survey of the surrounding region could not be made. There seemed to be no central crater present, however, and the highest part may be the remains of a portion of the rim. There is a range of hills, about two miles west of the summit, which runs parallel with the coast line, and have an elevation of about $1,200 \mathrm{ft}$. These hills rise abruptly from a broad, flat plain just east of them, which has an average elevation of $900 \mathrm{ft}$. It is possible that this plain may be the floor of an old crater, the rim of which has been mostly removed.

A few herbaceous halophytes grow on the sand beaches near where we anchored. There was also a low thicket of bushes of Laguneularia racemosa bushes growing here. Other than these no halophytes were found.

All of the vegetation of the south and southeast sides of the island below an elevation of $450 \mathrm{ft}$. consists of species $w^{\text {h }}$ inh are usually found on the lower and dryer parts of these islands. They are smaller and fewer in number, however, than is usually the case, a condition that may be due to the very seanty soil on these parts. The lava on this part of the island is bare in most places, and the only soil to be found is in the lava erevices. In consequence of this condition, a large part of the surface is not suitable at present for the support of higher plants. The trees of Bursera graveolens are small, seldom exceeding a height of 8 ft. Usually they are mere bushes. Besides the small Bursera trees, Opuntia galapageia is the only other species which reaches the size of a tree in these lower regions. It occurs here abundantly, and has weak spines and elosely arranged branches. Euphorbia viminea forma castellana is the most common bush in this region. It is about the only one that oceurs in mass, all other bushes being scattered. This speeies seems to be better adapted to maintain an existence under the sterile conditions than most of the other species found here. Other bushes found 
growing in this region, less abundantly than the above are: Cordia lutea, Castela galapageia, Croton Scouleri var. brevifolius, Euphorbia articulata, Prosopis dulcis, Scalesia Hopkinsii, Telanthera echinocephala, and Waltheria reticulata. The lava ridges are often found to be more or less covered with vines of Ipomoea Habeliana, and in various other places on the lava, I. Kinbergi was found growing and in blossom at the time of our visit. Such grasses as Aristida suspicata. Cenchrus platyacanthus, Leptochloa albemarlensis and L. Lindleyana grew with more or less abundance in the lava crevices. On the older beds of volcanic cinders there was very little vegetation other than occasional bunches of Cereus nesioticus; the more recent beds of cinders were bare.

A change, readily noticed, takes place in the regetation at about $450 \mathrm{ft}$. elevation evidently brought about by the greater amount of moisture and a more abundant soil. There is a general thickening up and an increase in the size of the vegetation above this elevation. There are good sized trees of Bursera graveolens in this region, and also trees of Pisonia floribunda, which first make their appearance. Many of the trees and bushes, at this elevation and above, are heavily covered with Alectoria sarmentosa and other epiphytic lichens. Bushes and small trees of Zanthoxylum Fagara also occur, usually infested with Phoradendron Henslovii. Other bushes which oceur in this region and a little higher are: Chiococca alba, Erigeron tenuifolius, Lipochaeta laricifolia, and Lippia rosmarinifolia. Such ferns as Chelianthes microphylla, and Polypodium squamatum occur. Very little change takes place in the vegetation on the southwest side of the island below an elevation of $700 \mathrm{ft}$., probably due to the fact that this side receives less moisture than the south and southeast sides.

Practically all of the plants which occur below $500 \mathrm{ft}$. disappear by the time an elevation of $1,000 \mathrm{ft}$. is reached. The species that continue into this region from below, are, for the most part, those which first appeared around an elevation of $500 \mathrm{ft}$. and above. The region between 1,000 and $1,650 \mathrm{ft}$. elevation is covered with forests, on the southeast side, which are made up mostly of Pisonia floribunda, and Zanthoxylum Fagara. There is much undergrowth in these forests, consisting of bushes of Croton Scouleri var. grandifolius, Erigeron tenuifolius, Lippia rosmarinifolia, Psychotria rufipes, Scalesia Hopkinsii, Tourne- 
fortia psilostachya, and 'T. rufo-sericea, many of which are covred with vines of Cissampclos Pareira, and Elaterium cordatum. There are also many ferns among which are: Adiantum Henslovianum, Asplenium cristatum, Nephrolepis biserrata, Polypodium pectinatum, P. squamatum, and Trachypteris pinnata. Many herbaceous plants also oecur in this region.

There are open areas in the vegetation on the south side of the island between 1,000 and 1,300 ft. elevation, which are covered with grasses and lierbaccous plants. These areas extend in a more or less direct way up the side of the mountain, and are bordered by bushes which are heavily covered with a growth of brown Ilepatic, probably a speeies of Frullania. These areas are sueceded above by a heavy growth of bushes and small trees.

Above $1,650 \mathrm{ft}$. elevation, extending to the top of the mountain, there is a heavy growth of ferns which are often five feet or more in height. Among the ferns there are low stunted bushes of Zanthoxylum Fagara heavily covered with epiphytes.

The dry region" on this island extends to about $450 \mathrm{ft}$. on the southeast side, and to about $700 \mathrm{ft}$. elevation on the southwest side. Judging from the appearance of the vegetation as seen from a distance, this region must extend to an elevation of about $1,000 \mathrm{ft}$. on the north side. The transition region extends to an elevation of about 1,000 ft. on the south and southeast sides, and probably to within a short distance of the top of the north side. There is apparently but a narrow strip near the top, on this side of the mountain, that is covered with dark green vegetation, such as is usually found in the moist region of these islands. All of the country above an elevation of $1,000 \mathrm{ft}$. is covered with the plants usually found in the moist regions.

\section{Albemarle Island.}

Albemarle lies towards the west side of the archipelago and is the largest island of the group. It is about seventy-five miles long, and forty-five miles broad at its widest part, which is towards the southern end of the island. The island has the general shape of the letter $L$ the long limb of which extends in a general northwest and southeast direction. There are five large

\footnotetext{
- For a discussion of the botanical regions on these islands see: Stewart, A Botanical Survey of the Galapagos Islands. Proceedings of the California Academy of Sciences, fourth series, vol. I, pp. 206-211. 1911.
} 
mountains on the island which vary in height from 3,150 to probably over 5,000 ft., and several mountains of lower altitude. All of the larger mountains are extinct volcanocs each of which has an immense crater at its top. These craters are all inactive at the present time except the one northwest of Villamil, on the south side of the island, Sulphur fumes and other vapors issue from the floor of this crater at times, and there are also two small active sulphur volcanoes in it, each of which is surrounded by a large quantity of almost pure sulphur. There has been some volcanic activity at Banks Bay during the last few years, from small craters on the west side of the mountain. With these exceptions there has probably been no volcanic activity of the island for a great many years. There are many low hills on various parts of the island, some of which are small craters or blowholes, and others simply masses of volcanic debris.

\section{Banks Bay.}

Banks bay is a broad, open roadstead on the west side of the island, near its northern extremity. The main mountain at this place is a broad flattopped crater with steep sides, which probably rises to a height of over $5,000 \mathrm{ft}$. There is still a smaller mountain close to the north shore of the bay that has an elevation of 2,360 ft. according to the chart issued by the Hydrographic Office. There are also a number of smaller craters and hills around the base of the main mountain, and along it sides, which usually have an average height of less than $100 \mathrm{ft}$. The base of the main mountain is separated from the shore by a broad plain which is covered with beds of comparatively recent lava on which there is very little vegetation. There are places, however, on this plain which were not covered by the more recent flows of lava, on which there is a considerable amount of xerophytic vegetation.

Unfortunately this region was not explored botanically, so that all of the information concerning its flora is due to the kindness of other members of the expedition who visited this place. At least three botanical regions are represented here, viz.: the dry, transition, and moist regions, and possibly a fourth, as the vegetation around the top of the mountain appeared from a distance to be quite different from that lower down. With the exception of the transition, no estimate was made concerning the: extent in elevation of these regions. 
The shores support many of the sinaller halophytic plants found on these islands, and "large mangroves", probably Laguneularia racemosa, and Rhizophora Mangle, occur abundantly in places. The older lava around the base of the mountain is covered with forms usually found in the dry regions. There are oceasional specimens of an arborescent Cereus, and a low species of Opuntia occurs abundantly around the base, and on the sides of the mountain to an elevation of $1,600 \mathrm{ft}$. The trees in the lower regions are mostly of Erythrina velutina and Bursera graveolens, the last one of which was found to extend up to an elevation of $1,700 \mathrm{ft}$. on the side of the mountain. Many bushes and shrubs occur on the lower parts, but with the exception of Lipochaeta lariciolia, the names of these are not known. They are probably all of species usually common on the lower parts of these islands. Beds of "maidenhair fern", probably Adiantum Henslovianum, were found in a lava eavern at the base of the mountain. All together six species of ferns were noticed on this part of the island, but it is very likely that many more could be found if eareful eollecting were done in this region. Croton bushes are abundant, and occur to an eleration of $2.300 \mathrm{ft}$. as high as this mountain was explored by the members of the party who visited this part of the island. A "broad-leaved variety of Croton", probably C. Scouleri var. grandifolins, occurs high up on the side of the mountain, and "small-leaved varieties of Croton" oceur around its base. There are one or more flows of recent lava down the west side of the mountain which are bordered by a heavy growth of bushes and morning glory vin around an elevation of 2,300 ft. Above this there are forests which are apparently made up of an arborescent species of Scalesia, and other trees. Orchids, and "sword ferns" were also noticed in the upper regions visited.

\section{Tagus Cove.}

Tagus Cove is located on the west side of the island about opposite the northeast corner of Narborough Island. It has been formed from and old tufa crater the southwest side of which has been removed leaving a small and well protected bay inside. The inner walls of the erater form steep bluffs which surround it on all sides except the one open to the sea. In some places these bluffs are $600 \mathrm{ft}$. high, but they are much lower than this towards the north end of the cove at which place a small ravine enters it. 
There are also two other tufa eraters in this vicinity. The smaller one of these is located just north of the cove and contains a miniature salt-water lake, while the larger is situated about a mile south near the coast. This third crater has probably formed a small bay some time in the past, as its walls are broken down on the side next to the sea, similar in this respect to the crater that forms Tagus Cove. The opening has been closed, however, by a flow of lava across it, and is now filled with salt water which comes in through the cracks in the lava from the sea a short distance away. There are four islets in this lake, one of which has a small crater on it. It is evident from the description, given by Darwin in his Voyage of the Beagle, that this is the salt water lake that he describes as being located near "Banks Cove". The sides of all these craters are much cut up by gullies which have been eroded in them. All three of the tufa craters just described, are separated from the base of the mountain by a plain, about one and a half miles wide, which is covered with deposits of volcanic cinder northeast of the cove. These cinder deposits extend along the base of the mountain northward and are continuous with the lava beds in the Banks Bay region. The cinder beds do not extend south of Tagus Cove, however, as the country around the base of the mountain in this direction, is covered with deposits of tufa, which extend out to the coast and form eliffs $40-50 \mathrm{ft}$. high.

The mountain lies northeast of the cove and is the second one of the three mountains that make up the northem part of the island. The mountain at Banks Bay is the one furtherest north, and the one at Cowley Bay furtherest south in the chain. The west side of the mountain, opposite the cove, is rather steep to an elevation of $2,500 \mathrm{ft}$. There are extensive deposits of tufa below this elevation, in which deep canyons have been eroded, and small gullies are common everywhere. There are two flows of comparatively recent lava, eovering the tufa, and extending down the side of the mountain. They have evidently originated from small craters near an elevation of 2,500 ft. Deep fissures occur in these beds in places. The side of the mountain is covered with extensive deposits of partly disintegrated lava, above an elevaton of 2,500 $\mathrm{ft}$., which is similar but much older than the lava which has formed the flows down the side below this elevation. The north side of the mountain seems to be entirely covered with lava. 
The top of the mountain is $4,000 \mathrm{ft}$. above sea level so that this is probably the third highest mountain on the island, and the fourth highest in the arehipelago, the mountains at Banks Bay, Iguana Cove, and the one on Narborough Island exeeeding it in height. There is an immense erater at the top which is about four miles long and thrce broad as nearly as could be estimated. The inner walls of the crater are nearly perpendicular in places. The floor forms a broad flat plain, possibly $500 \mathrm{ft}$. below the rim, which is eovered with voleanie ashes, and beds of basaltic lava, and einders. There is a somewhat smaller erater inside the larger one.

The tufa hills in the vicinity of the eove are covered with a sparse growth of low bushes the most eommon speeies of which are: Aeaeia macracantha, Croton Seouleri var. Maeraei, Euphorbia diffusa, Lipochaeta laricifolia, and Waltheria reticulata. There are also a few low trees of Bursera graveolens with rounded crowns, and a considerable amount of Opuntia insularis. There are many places where the ground is nearly bare of vegetation, and although we visited here in Mareh at the end of the rainy season, the prospeet was far from inviting. Several grasses oecur in these open areas among which are: Aristida subspicata, Anthephora hemaphordita, Bouteloua pilosa, Cenchrus granularius, and other herbaceous plants.

With the exeeption of an oecasionai specimen of Cereus selerocarpus the lava beds around the base of the mountain are bare of vegetation except in protected places where a few grasses and other small plants occasionally appear. On the flat area south of the lava beds, which is covered with tufaceous soil, the vegetation is thicker than it is on the tufa hills but is made up largely of the same species with the addition of a few others. Bushes and small trees are common here especially along the edges of the lava beds where they often grow to a larger size and occur in greater numbers than elsewhere. A few ferns are to be found in protected places in this region.

The tufa deposits above the base of the mountain are covered to a considcrable elevation with forms which are practically the same as those on the plain below, except that the arrangement is somewhat different, there being many open areas which are covered with grasses and other herbaceous plants. The canyons hore often have a heavy growth of Croton and Gossypium bushes which grow much taller than they do in the more exposed places 
outside the canyons. There is no very marked change in the character of the vegetation to an elevation of 2,500 $\mathrm{ft}$., as far as the tufa reposits extend, except that the vegetation thickens up in places and such conspicuous forms as Pisonia floribunda, Tournefortia rufo-sericea, and Zanthoxylum Fagara are added. The two lava flows down the side of the mountain, which cover the tufa deposits, are bare of vegetation except for occasional bushes of Erigeron lancifolius, Euphorbia viminea, and Waltheria reticulata, while the only plant of tree-like proportions is Cercus sclerocarpus. In the deep crevices of this lava, however, there is a more abundant vegetation as trees and bushes of Bursera graveolens, Cordia lutea, and Zanthoxylum Fagara are to be found, as well as a few ferns, among which are Asplenium formosum and Notholaena sulphurea.

The side of the mountain above an elevation of 2,500 ft. is covered in most places with low bushes, the most common one of which is Lipochaeta laricifolia. This condition continues to within about $150 \mathrm{ft}$. below the rim of the crater, where there is a narrow zone covered with a dense, and almost an impenetrable growth of Pennisetum exalatum. The rim of the crater is covered with bushes of Cordia galapagensis, Croton Scouleri var. Macraei, Dodonaea viscosa var. spathulata, Lantana peduncularis, Maytenus obovata, Telanthera nudicaulis, and Scalesia microcephala. Opuntia myriacantha also occurs here but the specimens are smaller and not so profusely branched as they were lower down. There are a number of herbaceous plants and ferns among the other vegetation. The vegetation on the floor of the erater appeared to consist of occasional specimens of Cereus sclerocarpus and clumps of Dodonaea bushes.

It seemed impossible to divide this side of the mountain into botanical regions, as was done at the most of the other places visited. There is a great similarity in the regetation all over this side, and the forms which occur at the top of the mountain are mostly of the same species which occur at or near the base. This rather peculiar condition is probably due to the fact that this side of the island gets very little of the moisture which is brought to the opposite side in the form of fog banks. Mr. R.. H. Beck visited the south side of this mountain, in his search for tortoises, and reported it to be less sterile than the west side A small lateral crater, which occurs on the south side, appeared to be heavily covered with vegetation, when seen from the west side of the mountain. 


\section{Couley Bay.}

Cowley Bay is located on the east side of the island near its center. 'l'he shores around the bay and along the adjacent coast north of here, are composed of low cliffs of pumice and occasional pebble and sand beaches. A plain, covered with partly disintegrated pumice, extends inland from the shore to the base of the mountain, a distance of about half a mile. The east side of the momntain rises rather steeply to $2,000 \mathrm{ft}$., and is covered to this elevation witl partly disintegrated pumice, similar to that on the plain below. Occasional ridges of lava protrude through the pumice in places so it is likely that these deposits are not very thick. The slope is more gradual above $2,000 \mathrm{ft}$. and continues so to within a few hundred feet of the rim of the crater. The sides of the crater's l'm are quite steep. Apparently all of the mountain side above an elevation of 2,000 ft. is covered with basaltic lava which has beeome partly broken down into soil through whieh lava boulders project forming a rather rough surface in most places. The side of the mountain, a short distance south of the bay, is covered with deposits of recent lava to a considerable elevation. The west side of the mountain was not visited, but it was noticed while sailing past this side of the island, that the vegetation was quite heary here so it is likely that this side of the mountain is covered with lava and not pumice.

There are but few halophytic plants in this vicinity, possibly due to the steep and unstable nature of the shores. A few bushes of Laguncularia racemosa were noticed, and a small grove of trees of Rhizophora Mangle were noticed a mile or two furthel south.

The region near the shore is almost bare of vegetation in many places, and with the exception of the more recent beds of lava on some of the other islands, it is the most sterile place botanically that we visited. What little vegetation there is here is very much scattered and consists largely of low Bursera and Croton bushes, and bushes of Cordia lutea, Discaria pauciflora, Dodonaea viseosa, Lipochaeta laricifolia, Maytenus obovata and Scalesia gummifera, all of which are rather stunted except when they occur in proteeted places. We visited this place during the dry season but it is not likely that conditions would be much more inviting during the rainy season, because very few remains of amnual plants were found. 
The lower slopes of the mountain are more heavily covered with vegetation than is the plain just mentioned, but even here there are often areas of a considerable size which have scarcely any vegetation on them. The species which occur on the plain also occur on the side of the mountain in greater number, and many of them that were stunted on the lower part, reach their normal size around an elevation of $1,000 \mathrm{ft}$. The increase in the humidity of the atmosphere is shown at this elevation, and above, by the large amount of Usuea longissima, and other lichens, which cover the vegetation to such an extent as to give it a grayish appearance. A number cf mesophytic plants were first seen around 1,300 ft. elevation, the most noticcable of which were: Pisonia floribnda, Psidium galapageium, and Scalesia microcephala, the last of which forns a zone on this sicle of the mountain to an elevation of $1,650 \mathrm{ft}$. There are also a grat many Bursera trees at an elevation of $1,200 \mathrm{ft}$. and above. Below this they were few in number. Ferns begin to appear at a slightly higher elevation.

There is an abrupt change in the appearance of the vegetation at an elevation of $2,000 \mathrm{ft}$. The character of the soil also changes here from pumice to disintegrated lava mixed with vegetable mold, so that the change in the vegetation is due more to an increase in the number and size of plants than to a sudden change of forms. There are heary forests here made up of trees of Bursera graveolens, Pisonia floribunda, Psidium galapageium, and Zanthoxylum Fagara as well as many species of bushes the most of which were found at a lower elevation although usually smaller in size. The trees are often covered with vines of Cissampelos Pareira, and fruticose lichens continue to be abundant. Ferns are also abundant, the common species being Adianaum concinnum, Doryopteris pedata, Polypodium pectinatum, and Trachypteris pinnata. Small specimens of Opuntia myriacantha were seen at this elevation and they continue to within a few hundred feet of the top of the mountain according to Mr. R. H. Beck, who visited this region.

The sides of this mountain were not explored botanically above an elevation of $2,100 \mathrm{ft}$. From the top of a tree at this elevation, the whole of the country beyond could be seen. The character of the vegetation did not seen to change until the steep slope, below the rim of the crater is reached. Just below the rim, in several places, there were light green areas which, according to 
Mr. Beck, are covered with a tangled growth of bushes and morning glory vines.

The conditions on this side of the mountain are such that it. is very difficult to determine the extent in elevation of the botanical regions, the nature of the soil being such as to eause xerophytic plants to predominate higher up than would probably be the case if the lower part of the mountain was covered with a more suitable soil. The transition region evidently begins around an elevation of $1,200 \mathrm{ft}$. and it probably extends up to within about $500 \mathrm{ft}$. in elevation, from the top of the mountain.

\section{Iguana Cove.}

Iguana Cove is a slight identation in the shoreline on the southwest side of the island. It is somewhat protected from the direct action of the swell, but owing to its small size, it does not afford an anchorage inside. The anchorage is just outside the cove, but owing to the fact that there are jagged rocks projecting from the water a short distance from it, on which the swell breaks heavily, it is dangerous to anchor here except in calm weather. The shores are preeipitous in this vicinity, being made up of bluffs, which in places rise to a height of $200 \mathrm{ft}$. These tall bluffs do not eome down to the shore, however, except in one place; in other places there is a low flat plain intervening between them and the shore. In the vieinity of Christopher Point, just north of the cove, the shores are made up of low lava eliffs, and the country back of them is covered with rather recent lava on which there is apparently very little vegetation. In the immediate vicinity of Christopher Point there are many small eraters and blowholes which rise fifty or more feet in height, and which give the surrounding country a weird and grotesque appearance. South of the cove the shores are made up of low cliffs with oceasional shelving beaches of gravel and sand.

The mountain northeast of Imuana Cove is a broad flat-topped crater which probably rises to a height of 5,000 or more feet. As the weather was very bad when this place was visited, no attempt was made to reach the top of the mountain. The sides are very steep liere, and are covered with a considerable amount of soil, composed of disintegrated lava and regetable mold, which supports a heary growth of vegetation. The north side of the mountain is not so steep and is eovered with beds of barren lava in 
which there are occasional islands of older lava which are covered with xerophytic vegetation.

The botanical conditions in the vicinity of Iguana Cove are rather unique, as it is the only place on the islands where an extensive mesophytic vegetation oceurs near sea level. It is very likely that the steep slope has something to do with this, as no such conditions are found a short distance south of the cove where the slope is more gradual.

The halophytic flora is of no eonsequence here due probably to the steep shores. There are mangrove swamps, however, along the north shore of this part of the island between Christopher Point and Elizabeth Bay, and on the south shore between Essex Point and Cape Rose.

The flat area at the base of the cliffs, just south of the cove, is covered with a heavy growth of bushes consisting for the most part of: Cordia Hookeriana, Cryptocarpus pyriformis, Tournefortia rufo-sericea, and Zanthoxylum Fagara. This condition continues for some distance down the coast was found out by some members of the party who attempted to come overland. The sides of the cliffs just back of the cove, are pendicular so that it is difficult to scale them except, in a few places where they are somewhat shelving. In such places there are a few trees and bushes, and a considerable number of herbaceous plants and ferns. Above the top of the cliff there is a heavy growth of vegetation consisting of trees of Bursera graveolens, Pisonia floribunda, Scalesia Cordata, and Zanthoxylum Fagara, the last of which is usually heavily covered with Phoradendron Henslovii. There are usually thick tangled masses of bushes which are heavily overgrown with such vines as Cissampelos Pareira and Ipomoea Bona-nox. Many ferns, both epiphytic and terrestrial, occur here.

Owing to the rainy weather, while we were at this place, no plants were collected above $500 \mathrm{ft}$. The conditions at this elevation were about the same as those near the tops of the cliffs above the cove, except that there were occasional open places in the vegetation, which were covered with ferns and grasses. These areas get larger a little higher up. Mr. R. E. Snodgrass climbed about half way up the side of this mountain when he visited these islands several years ago. He has told me that apparently the rest of the way up, the vegetation is made up of dense fern brakes with irregular rows of shrubs running through 
them. It was noticed from the shore that the vegetation had a streaked appearance about half way up the side of the mountain. It appeared to be made up of alternating light and dark bands, and suggested that there might be flows of different kinds of lava in this region, each of which presented conditions peculiarly adapted for the growth of certain species of plants.

The country around the top of the mountain was examined through a field glass on a clear day later in the season as we were sailing past this part of the island. The vegetation appeared to be smaller than lower down and it was rather grayish in color instead of dark green. It is very likely that the upper part of this mountain reeeives less moisture than does the middle. part. The upper part of this mountain could be plainly seen from the top of the mountain at Villamil when we visited there. The lower part of the mountain, however, was entirely hidden by the fog at this time. It was also noticed that much of the soil on top of the Villamil mountain was dry while lower down it was wet. The fog banks apparently hang low when they strike the islands.

\section{Turtle Cove.}

Turtle Cove is on the south side of the island about six miles west of Villamil. The coast in this vieinity is low and rocky with oceasional sand beaches, while back of the coast the country is low and covered with beds of basaltic lava for a considerable distance inland. There are springs of comparatively fresh water and pools of strongly brackish water in the vicinity of the shore and farther inland.

There were large trees of Avicennia officinalis on the sand beach where we landed, back of which there is a swampy area covered with a dense growth of Conocarpus erectus and trees of Rhizophora Mangle. Rhizophora occurs for some distance inland, surrounding the pools of brackish water. It also oceurs in isolated patches on the open eoast, but owing to the fact that the surf breaks heavily here at times, none of these are extensive. Thickets of Laguneularia racemosa are also to be found in places. in the vicinity of the shore and there are quite a number of small trees of Hibiscus tiliaceus, and bushes of Tournefortia rufo-sericea.

The vegetation on the inland country consists of plants usualy found in the dry regions except that there is an unusually 
large number of trees of Hippomane Mancinella. Other common trees are those of Bursera gravcolens and Opuntia myriacantha. The country adjacent to the coast, just east of this place, is covered with dense thickets of Cryptocarpus pyriformis apparently to the exclusion of all other vegetation of any size. West of here, in the vicinity of Cape Rose, there are extensive deposits of volcanic cinders on which the vegetation is very open, probably due to the fact that the lava has disintegrated but little. What few plants that do occur here are for the most part, the ones that are commonly found in the dry regions of these islands.

All of the country which lies between the mountain at Iguana Cove, and the one northwest of Villamil is low, probably in no place exceeding an elevation of $200 \mathrm{ft}$.

\section{Vilamil.}

Villamil is on the south side of the island about seven miles. northwest of Brattle Island. A settlement of about one hundred and fifty people was established here some years ago, by Mr. Antonio Gil of Guayaquil, Ecuador. A considerable industry in hides, molasses, and sulphur is carried on, the products of which are sent to Guayaquil by means of a small vessel which makes periodic trips to the mainland. A part of the settlement is located near the shore, but the most of it is about twelve miles inland, at an elevation of 1,300 ft., where there are plantations of sugarcane, bananas, and other tropical fruits and vegetables.

Villamil Bay is surrounded by low beds of basaltic lava, but west of the settlement on the open coast, there are extensive sand beaches. These are continuous with a broad sand-flat just back of them, which extends back for about half a mile. The country for several miles inland is flat and is covered with beds of basaltic lava and volcanic cinders which usually lie almost horizontally. There are numerous crevices in the lava, in some of which there are pools and springs of nearly fresh water. Owing to the low elevation of this part of the island, these springs usually occur only a few feet below the level of the ground. There is a considerable amount of precipitation on the upper part of this island, in the form of fog and rain. There is not sufficient soil to retain this water, however, so it percolates through the lava and comes out again near sea level. On this account the water is usually slightly brackish even at a considerable distance inland. 
'The flat country extends inland for about four miles, to the base of the mountain. Above this the slope is very gradual to an elevation of $500 \mathrm{ft}$. So far as could be observed, this side of the mountain is covered with volcanic cinder, which has become slightly disintegrated and mixed with vegetable mold, forming a scant soil. The slope is less gradual above $500 \mathrm{ft}$. and continues so to an elevation of $2,400 \mathrm{ft}$. This part of the mountain side is rather rolling and slightly terraced in places. There is sufficient soil over the upper part of the mountain to completely cover the lava except on ridges and other exposed places. The slope of the mountain side is quite abrupt above $2,400 \mathrm{ft}$. to the rim of the erater, which has an elevation of $3,150 \mathrm{ft}$.

As near as could be estimated the crater is about seven miles long and four miles broad, the greatest diameter being approximately east and west. The floor of the erater is flat at its eastern end and is filled with numerous crevices through some of which vapors issue periodically. There is a prominent ridge near the center of the crater which rises gradually in height until at its west end it is nearly as high as the rim. A șmall active sulphur voleano is situated on the south side of this ridge, and still another larger one at its west end around both of which there are deposits of sulphur. It is from this place that the inhabitants obtain the sulphur which they export to Ecuador.

Small swamps of Rhizophora Mangle occur in places around Villamil Bay, and trees of Avicennia officinalis, and bushes and trees of Laguneularia racemosa are to be found in sereral places near the coast. Quite a grove of these occurs near the settlement. Along the sand beaches west of the bay, there are many small halophytic and semihalophytic plants such as: Cryptocarpus pyriformis, Heliotropium curassavicum, Ipomoea Pes-caprae, and Scaevola Plumieri. The sand flat, back of the beach, is covered with a dense growth of Sporobolus virginicus in which there are small groves of Hippomane Mancinella trees, and bushes of Cryptocarpus pyriformis. In places around the edges of the sand-flat there are thickets of Conoearpus erectus, some of which form trees twenty-five or more feet high.

There is a low area of limited extent about a mile west of Villamil in which the soil is kept moist by the water which eomes down through the lava from the interior. There are quite a number of mesophytic plants here. Vines of Argyreia tiliaefolia and Cissampelos Pareira cover the rocks in places and there 
is a small grove of trees of Anona glabra and ferns. The inhabitants have planted a garden in this place which has been quite successful as bananas and other tropical plants grow there. The change from xerophytic to the mesophytic type of vegetation is very abrupt here, as such pronounced xerophytes as Lantana peduncularis, Opuntia myriacantha, and Prosopis dulcis are found growing only a few feet away from the mesophytic plants enumerated above. There are several low marshy areas, filled with brackish water, in the vicinity of the settlement, in which there is a heavy growth of Eleocharis mutata. The stems of this plant are used by the inhabitants for making mats. The higher land between these marshes is covered with low and rather open forests consisting of trees of Acacia macracantha, Bursera graveolens, Hippomane Mancinella, and Opuntia myriacantha, among which there are bushes of Chiococea alba, Clerodendron molle, Cordia lutea, Gossypium barbadense, and bushes and small trees of Zanthoxylum Fagara on which Phoradendron Henslovii is often found. In many of the lava crevices, which are deep enough to reach the ground water, there are large bunches of Cyperus ligularis.

On the broad plain some distance inland, there are beds of basaltic lava and voleanic cinder of a considerable width. The basaltic lava is often heavily covered with vegetation and in one place an entire flow is covered with a forest of Opuntia myriacantha trees, underneath which there are low dense thickets of Euphorbia viminea and occasional bushes of Acacia macracan tha. Cyperus Mutisii was found growing abundantly in the smaller crevices of the lava in this area. The vegetation on the cinder deposits, however, is very open and consists mostly of occasional bushes, or small clumps of bushes, of Clerodendron molle, Erigeron tenuifolius, Lippia rosmarinifolia, and Sealesia gummifera on many of which there was a dense growth of vines of Cardiospermum galapageium, and Passiflora subrosa. Between the bushes the ground is often bare for some distance.

In one place, several miles inland, there is a low area which had the general appearance of having been filled with water at some time. There is much more soil here than in any place in this vicinity. There are pools here which seem to contain water the most of the time, around which Cyperus laevigatus and Sporobolus virginicus grow. Groves of Hippomane Mancinella grow in this area, in the shade of which there are bushes of Cae19-S. A. 
salpina Bonducella, Cryptocarpus pyriformis, Discaria pauciflora, Scalesia gummifera, and Solanum verbascifolium. In the more open places in this area there were large bunches of Panicum fasciculatum and other herbaccous plants. On barren lava beds and on exposed ridges in this vicinity, Cereus sclerocarpus was the only plant that grew to any considerable size.

A change takes place in the vegetation between an elevation of 100 and $200 \mathrm{ft}$. where many of the plants common below disappear, the most common of which are: Acacia macracantha, Castela galapageia, Cereus sclerocarpus, Discaria pauciflora, Euphorbia viminea, and Waltheria reticulata, while such prominent woodland plants as Pisonia floribunda, Psidium galapageium, and Scalesia cordata begin to appear along with ferns and other plants, which are found abundantly higher up. There is a general thickening above an elevation of $200 \mathrm{ft}$. and fruticose lichens are very abundant on trees and bushes.

Sapindus saponaria was first seen around $250 \mathrm{ft}$. elevation. There are only occasional trees of this species at this elevation, the dense Saponaria forests not beginning for another hundred feet or so in elevation. Scalesia cordata also increases in abundance so that the forest trees throughout the moist region consist mostly of these two species. There is a heavy growth of bushes in these forests, increasing with the elevation, which consist largely of the following species. Clerodendron molle, Croton Scouleri var. grandifolius, Erigeron tenuifolius, Psychotria rufipes, Tournefortia psilostachya, T. pubescens, and T. rufo-sericea. There are many ferns both terrestrial and epiphytic, the common epiphytic species being: Polypodium lanceolatum, and P. lepidopteris, while on the higher branches of many of the trees there are large bunches of Lycopodium dichotomum. Other common epiphytes in this region are Ionopsis utriculariodes, Peperomia galapagensis, P. Stewarti, and Tillandsia insularis. There are a large number of trees of Hippomane Mancinclla in the forests at an elevation of $600 \mathrm{ft}$. but none were found below this, except near sea level.

A considerable amount of the forest has been cleared away between 600 and $1,300 \mathrm{ft}$. elevation. Much of this area has since been neglected and has grown up in bushes of Tournefortia rufosericea which are heavily covered in places with vines of Argyreia tiliaefolia, and Ipomoea Bona-nox. There is also usually a heavy growth of grass in between the bushes, and brakes of Pter- 
is aquilina var. esculenta are not uncommon. The forest bordering the cleared area seems to be made up mostly of the same forms found around an elevation of $600 \mathrm{ft}$., where the cleared area begins, but the lower part of it was not carefully explored. The vegetation becomes much thinner in the uncleared areas above 1,200 ft. elevation and with the exception of an occasional tree of Sapindus saponaria, there are no trees of large size. The country is covered with open woodland made up largely of small trees and bushes of Croton Scouleri var. grandifolius, Scalesia cordata, Solanum verbascifolium, Tournefortia rufo-sericea, Urera alceaefolia, Zanthoxylum Fagara, many epiphytic plants and ferns. There are many park-like areas in the woodland which are covered with grasses. The trees become smaller and more scattered to an elevation of $1,500 \mathrm{ft}$., where they end rather abruptly.

The side of the mountain above $1,500 \mathrm{ft}$. elevation is somewhat rolling and is covered with grassland on which large numbers of cattle graze, which are slaughtered by the inhabitants of the island for their hides. Paspalum conjugatum is the principal species of grass found in this region. This condition continues to an elevation of $2,400 \mathrm{ft}$, above which there is a decrease in the amount of grass and a large increase in the fern flora. Small tree ferns, Hemitelia multiflora, and other large species of ferns are common from here to the top of the mountain.

There is a great difference in the vegetation of the outer and inner sides of the southern rim of the crater, where the most of the collecting around the top of the mountain was done. The outside of the rim at this place is mostly covered with small vegetation consisting of ferns, club-mosses, and small herbaceous forms, all of which lie close to the ground, and it is only in places which are protected from the wind that plants of any size are to be found. Just over the rim of the crater, however, there is a considerable growth of bushes of Duranta repens, Erigeron lancifolius var. glabriusculus, Solanum verbascifolinm, Zanthoxylum Fagara, and other bushes. Hemitelia multiflora also occurs. here in large numbers and such other ferns as Asplenium Serra, Dryopteris parasitica, Elaphoglossum muscosum, Polypodium: aureum, and Polystichum aculeatum abound.

A gradual change from a mesophytic to a xerophytic vegetation can be readily noticed as one travels around the southern rim of the crater towards the northwest side, but as our time was limited when this region was visited, no collections were made. 
The floor of the erater is $400 \mathrm{ft}$. below the rim, and was examined near the west end, in the vicinity of one of the active volcanoes. Here were found patehes of Sporobolus indieus covering considerable areas in places while other areas were eovered with Gnaphalium luteo-album, the gray color of which eaused them to stand out prominently when the floor was viewed from the rim. There were also occasional specimens of an arborescent species of Cereus, and low stunted speeimens of Opuntia myriacantha. An oceasional tree of Zanthoxylum Fagara was seen, usually close to the erater's wall. There is a eonsiderable growth of stunted bushes in places consisting mostly of: Clerodendron molle, Dodonaea viscosa, Euphorbia equisetiformis, and Lipochaeta laricifolia. There were brakes of Ptcris aquilina var. eseulenta in one place, but outside of this, ferns are few at this end of the erater.

The northwest side of the mountain seems to be covered with grassland, which is much drier than are the south and southeast sides. At least it appeared to be as far down on this side as we could see from the top of the mountain. The soil on the rim of the crater was also much dryer on this side than it was on the southeast side.

The dry region is confined largely to the broad flat plain at the base of the mountain at this place. As near as could be determined it does not extend above an elevation of $150 \mathrm{ft}$. Above this many of the mesophytic forms appear, and there is a large amount of fruticose liehen on the vegetation, indicating a greater humidity. The transition region forms a narrow belt along the base of the mountain, the upper limits of which reach to an elevation of about $350 \mathrm{ft}$. The lower part of the moist region is covered with dense forests of Saponaria, and Sealesia trees, while on the upper part the vegetation consists mostly of bushes, and small trees with open spaces between them at intervals. Near the upper limit of this region, around an elevation of 1,500 ft., there are only low bushes. The grassy region extends from $1,500 \mathrm{ft}$. nearly to the top of the mountain.

\section{BarRington IsLand.}

Barrington is situated ten miles southeast of Indefatigable, and twenty-six miles west of Chatham Island. It is one of the smaller islands of the group, and it is of low altitude the most 
of it not reaching an elevation of over $350 \mathrm{ft}$. There is a hill near the northwest side, however, which attains an elevation of $650^{\circ} \mathrm{ft}$. This hill ends abruptly at the top of a tall bluff which drops almost straight downward into the sea. The shores of the island are made up of low lava cliffs for the most part, but there is a small bay on the northeast side, which is surrounded by sand-beaches. This bay is sheltered by a small islet and a reef, Although this bay can not be entered by vessels, it nevertheless affords an excellent landing place for boats.

Topographically the island is made up mostly of alternating ridges and valleys which have a general trend towards the southeast. The ridges, in a general way, are $100 \mathrm{ft}$. higher than the valleys, and are covered with tumbled masses of lava. The valleys, on the other hand, usually have a considerable amount of soil in them, the most of which has probably been formed on the sides of the ridges and washed down. The soil varies from a light brown to an ochre color, and is very light in texture. The lava all seems to be basaltic in character and is evidently quite old as it has become stained to a redish-brown color.

The only plants found on the sand-beaches surrounding the bay, were bushes of Cryptocarpus pyriformis, and mat-like growths of Sesuvium Edmonstonei both of which are not exclusively halophytic in their habits. The shores on other parts of the island are too steep to support halophytes. A short distance inland from the beach there are low thickets of Discaria, and Maytenus bushes.

Owing to a low altitude, all of the vegetation in the interior of the island is very xerophytic in character, and about the only noticeable change that takes place in the vegetation towards the higher parts is the greater abundance of fruticose lichens. The most noticeable plants are the large trees of Opuntia myriacantha which grow in great numbers over the most of the island. Small trees of Bursera graveolens also occur, much infested with lichens. There was a fair growth of bushes in most places, consisting for the most part of such species as: Cordia lutea, Corton Scouleri, Gossypium barbadense, Lantana peduncularis, Telanthera echinocephala and Scalesia Helleri, the last one of which was the only conspicuous green plant to be found on the interior of the island at the times we visited it. In the valleys between the ridges there were small areas which are covered with a growth of Euphorbia viminea forma barringtonensis. In other 
places in these valleys where the soil is loose there is an abundance of Coldenia fusea.

This island was visited during the months of July and Oetober, in eonsequence of which the anuual regetation, which comes on during the rainy season, was missed entirely. Very few remains of such plants were found on either of our visits as goats have been introduced upon this island during the last few years which eat up all of the edible vegetation as fast as it grows. Even the trunks of the large Opuntia trees do not escape their ravages.

\section{BindLoe IsLañ.}

This island is the largest of the group of three which lie some distance north of the main part of the arehipelago. It is eight miles long, six and one-half miles broad, and its highest part attains an elevation of $800 \mathrm{ft}$. according to the chart issued by the Hydrographic Office. When seen from a distance the island appears to be made up of numerous small peaks which vary in elevation. The greater part of the island is covered with beds of recent lava which consist mostly of voleanic einder. The whole of the north side, along which we sailed, is covered with such deposits, on which there are oceasional exposures of older lava which support a considerable amount of vegetation.

We anchored on the northeast side of the island near where a broad strip of country, covered with deposits of tufa, extends down to the shore. This area is covered with vegetation, apparently the largest continuous body of such on the island.

A few small green patches, evidently halophytic plants of of some kind, were noticed along the north shore of the island as we were sailing past it. With this exception, no halophytes were seen, as the shores are too steep in most places to support them.

The vegetation is arranged in irregular elumps in the vicinity of the shore with broad open lanes between them. The vegetation here is made up mostly of low bushes of Euphorbia amplexicaule, E. articulata, Castela galapageia, and low thiekets of Opuntia. This open arrangement disappears inland and the country is heavily covered with xerophytic regetation. The only trees found here are those of Bursera graveolens which grow quite large considering the very dry conditions whieh prevail. They are sometimes covered with vines of Ipomoea Habel- 
iana, the only place on the islands where this species assumes the climbing habit in such a pronounced way.

The edges of recent flows of lava are often bordered with bushes of Cordia lutea, and Waltheria reticulata forma intermedia, both of which occur in other places but less abundantly.

No collecting was done on the upper part of the island, but according to Mr. Beck, who visited this part, the country is covered with beds of recent lava which have but little vegetation on them. There are a few moist places, in the vicinity of steamvents, in this region, around which such ferns as Ceropteris tartarea, Nephrolepis biserrata, and Polypodium squamatum grow to some extent. The whole of the island may be included in the dry region.

\section{Brattle Island.}

Brattle is a small island, that is situated about four miles off the south side of Albemarle Island near its eastern end. It is a semilunar in general outline and is the remains of an old tufa crater the south and west sides of which have been eroded away, except in two places, where there are small islets. The top of the island is $275 \mathrm{ft}$. above sea level, and the sides are very steep and much eut up with gullies and ravines. Owing to the steep nature of the shores landing is difficult, and can only be done with safety on the north side, when the water is comparatively still.

The greater part of the surface of the island is bare of vegetation, a condition that is probably due to the steep sides and the loose soil, which is composed of volcanic ashes and small bits of lava loosely cemented together.

The most common plant on the island is a low bush which is covered with thick, succulent leaves, and which forms thickets around the top in various places. This plant was neither in flower or fruit at the time the island was visited so it could not be identified with certainty. Bushes of Croton Scouleri occur along the sides to some extent, but they are stunted and the leaves are smaller here than is usually the case with this species. Three species of herbaceous plants: Coldenia fusca, Ipomoea Kinbergi, and Tribulus cistoides were found at the top, as well as the remains of several grasses. Two lichens, Ramalina complanata and Rocella peruensis are also found. 


\section{Cimarles Island.}

With the exception of Hood, this is the most southerly island in the group. It is located about thirty-seven miles south of Indefatigable Island. The island is ten miles long and eight miles broad. It reaches an elevation of $1,780 \mathrm{ft}$. at its highest point. Geologically it is probably one of the oldest islands in the group, and voleanic activity upon it has evidently long since ceased. There are no deposits of even comparatively recent volcanic material upon it.

In approaching the island from the south, one is impressed with the number of large craters on it. Fourteen of these were counted, seven of which were larger than the rest. The tops of the most of the craters are evenly rounded, and it was found out later that the southeast sides of many of them were broken down. The slope is quite gradual from the shore to the central region, on all sides but the east. This side was not visited, but in sailing along the shore, the slope appeared to be rather steep, and was covered with xerophytic vegetation among which were large number of Cereus.

There is a fair amount of soil in most places, composed of volcanic ashes and bits of lava. There are exposures of lava, however, on which there is but little soil, but they are less common than on other islands visited. The central part of the island is covered with a plateau, several miles square, which has an average elevation of $1,000 \mathrm{ft}$. Several large tufa craters are located on the plateau, which usually rise 500-800 ft. above it. Springs occur around the base of one of these, and a considerable amount of water is afforded by one of them. Such domesticated animals as: Cattle, hogs, goats, cats, and dogs have been introduced upon the island. The inhabitants from Chatham island often come here to dry beef for the use of the laborers on that island.

\section{Black Beach Road.}

Black Beach Road is located on the west side of the island and was the port for the settlement which was located on this island many years agro. A good trail leads inland from here so the central region is more accessible than on the most of the other uninhabited islands.

The shores are low and rocky in the vicinity of Black Beach Road, against which the surf breaks heavily at times. On thie 
account there are no halophytes to speak of except a small bunch of rather stunted mangroves a short distance south of the landing place.

The region north and esst of this place is covered with a fair amount of ashy soil through which the lava seldom appears. South of here, however, there are exposures of lava, covered for the most part with Croton bushes. Just back of the landing place there is a flat area covered with bushes and small trees of Maytenus obovata and Prosopis dulcis. Another small area occurs a few hndred yards north of the landing place near the coast, which is covered with tumbled masses of lava among which Cereus galapagensis, Lecocarpus pinnatifidus, Mentzelia aspera, and Scalesia decurrens grow.

The larger vegetation to an elevation of $450 \mathrm{ft}$. consists of trees of Bursera graveolens, and Opuntia galapageia. In the vicinity of the shore there are also trees of Cereus galapagensis. The vegetation is all rather open but there are a considerable number of bushes of Cordia lutea, Croton Scouleri var. Macraei, Lantana peduncularis, Maytenus obovata, Gossypium barbadense, and Vallesia pubescens. Acacia macracantha and Prosopis dulcis also occur in this region to some extent but they assume the size of trees around $450 \mathrm{ft}$. There are remains of an old settlement at this elevation which is marked by a grove of Geoffroea striata and other trees, as well as by a few other domesticated plants of smaller size. There was evidently a spring of water here at some former time but it was dry at the times this place was visited.

A decided change takes place in the regetation above an elevation of $450 \mathrm{ft}$. For possibly the first $200 \mathrm{ft}$. there are large bunches of bushes of Clerodendron molle, in between which are grasses and smaller plants. This is succeeded above by more open country on which there are occasional Bursera trees and bushes, the most common of which are, Capraria biflora, and Lipochaeta laricifolia. Perennial grasses grow between the bushes, to which a considerable number of annual forms are added during the rainy season.

The plateau region, around an elevation of 1,000 ft., is covered with stretches of rather open woodland, and meadow. The woodland usually occurs where the lava is exposed or reaches nearly to the surface of the ground. In these areas trees of Scalesia pedunculata are common but they do not grow to as large a 
size as they do on some of the other islands where this species occur's. Other trees in the woodland besides those that have evidently been introduced are: Pisonia floribunda, and Zanthoxylum Fagara, the last one of which is often heavily covered with Phoradendron Henslovii, as often happens when this tree grows where there is a considerable amount of moisture. Common bushes in the woodland are: Capraria biflora, Croton Scouleri varieties brevifolius and grandifolius, Erigeron tenuifolius, Psychotria rufipes, Tournefortia psilostachya, and T. rufo-sericea. The soil is ashy in the meadows, with small fragments of lava scattered through it. Grasses and herbaceous plants occur here, the common species being: Aristida subspicata, Eleusine indica, Eragrostis ciliaris, Acalypha parvula, Lippia canescens, Malvastrum americanum, Plumbago scandens, and Stachytarpheta dichotoma. Many evidences of former habitation appear in the flora throughout the plateau region as such introduced species as Ambrosia artemisiaefolia, Bixa Orellana, Datura Tatula, Inga edulis, Spondians purpurea, orange, lemon, and lime trees grow there in greater or less abundance. The lime trees are the most common of these, and there are areas of considerable size which are covered with them. They seem to spread mostly in the open meadows as there are but few of them in the woodland. Probably in time they will cover all of the open country in the plateau region. The limes and lemons are of good quality and many tons of them rot on the ground each year.

The main crater rises to a height of $1,780 \mathrm{ft}$., and is covered on the outside with a heavy growth of bushes of Lipochaeta laricifolia, to within about $400 \mathrm{ft}$. of the top. This condition is found on all sides but the south and southeast. The bushes gradually disappear towards the south side of the crater and their place is taken by a heavy growth of Stachytarpheta dichotoma. Above an elevation of 1,450 ft. the outside of the crater is covered with low bushes of Capraria biflora, occasional bushes of Tournefortia rufo-sericea, grasses and other herbaceous plants the last of which are dried up during the greater part of the year, giving this part of the mountain a very barren appearance the most of the time. One will be greatly surprised if he should climb the west side of this crater during the dry season. On this side Opuntia galapageia grows to an elevation of 1,300 ft. The other plants which occur here and above are of a xerophytie type and continue so to the top of the mountain. Upon going 
over the rim, into the interior of the crater this condition changes and the plants which occur. there are decidedly mesophytic Small trees of Acnistus ellipticus grow there which are covered with such epiphytes as: Lycopodium taxifolium, Polypodium lanceolatum, Peperomia ramulosa and leafy Hepatics. Ferns and herbaceous plants are also common in this vicinity. The sudden change in the character of the vegetation within such a short distance is due to the fact that the moist winds strike the inner side of the crater and keep the regetation damp the most of the time, while they pass directly over the top so that the moisture seldom descends far upon the leeward side. The inside of the crater is covered, a short distance below the top, with bushes and occasional small trees of Zanthoxylum Fagara all of which bear numerous epiphytic plants. Ferns are common in the crevices of the lava. The floor of this crater is covered with trees of Scalesia pedunculata and bushes.

There are several other craters in the upper regions which do not reach as great an elevation as the one described above. For the most part, they are covered with a heavy growth of lime trees and bushes on their leeward sides while the windward sides are covered with low bushes and herbaceous plants above an elevation of $1,300 \mathrm{ft}$.

It seems impossible to make out distinct botanical regions here as can be done on some of the other larger and higher islands of the group. For some reason or other, this island apparently does not receive as much moisture as do the other islands of similar elevation. In consequence of this the upper part, including the plateau, is covered with a mixture of both xerophytic and mesophytic forms, the last of which, however, are more abundant than they commonly are in the transition regions on the other islands. There are a few places in which there is a suggestion of a moist region but these are very limited in extent, dependent upon some very local condition or conditions. The country below an elevation of $1,000 \mathrm{ft}$. can be divided into open woodland below and bushy country above, the line of separation between the two being at about $450 \mathrm{ft}$. elevation.

\section{Cormorant Bay.}

Cormorant Bay is an open sheet of water situated on the north side of the island a short distance east of Post Office Bay. There are sereral sand beaches along the shore here on which Batis 
maritima, Lycium sp., Scaevola Plumieri, Sesuvium Edmonstonei, and S. portulacastrum grow quite commonly, while at the west end of the bay there is a small swamp of Rhizophora Mangle. A short distance back of the bay there is a small lake, the water in which has become saturated with salt and a layer has crystalized out which is thick enough in places to support one's weight. A mumber of trees of Avicennia officinalis grow in the water on the edge of this lake. There is a heavy growth of pneumatophores and mats of Sesuvium Edmonstonei in the water beneath these trees. There are some exposures of lava in this vicinity on which there is little vegetation besides Cacti and a few bushes. Around the base of a small erater, near the east end of the bay, there are bushes of Acacia macracantha, Cordia lutea, Cryptocarpus pyriformis, and Scalesia villosa. There is another small crater, about a half mile inland, the sides of which seemed to be covered with Bursera trees and Croton bushes.

\section{Post-Office Bay.}

Post Office Bay lies about two miles west of Cormorant Bay, just mentioned. This bay derives its name from the fact that the British Warship Leander placed a barrel on a post there many years ago, in which ressels which visited this place could deposit letters. The next vessel that called was supposed to take them out and carry them to their next port of call. Several of the members of the party, including the writer, mailed letters here which reached their destination some eighteen months later.

The interior region, on the north side of the island, was visited from this place, and was found to be much rougher than was the region near Black Beach Road on the west side of the island. There are several small craters on this part, the highest one visited having an elevation of $700 \mathrm{ft}$. There are broad valleys between the eraters in some of which there were low rocky areas which might have contained water at some time as there were rounded boulders in them which had the appearance of having been water-worn.

The coast, along the south side of the bay, is rocky with occasional sand beaches on which there are a few patches of Rhizophora Mangle, and trees of Avicennia officinalis. This, by the way, is the only place on the islands where Avicennia grows so 
close to the open sea that its roots were covered with water at high tide. There are also dense thickets of Laguncularia racemosa in one or two places near the shore. In the sandy soil near the shore there are thickets of Cryptocarpus pyriformis, and Discaria pauciflora.

The low areas in between the craters in the interior region, are usually covered with such a thick growth of bushes of Prosopis dulcis as to render traveling difficult. In such places Castela galapageia, Maytenus obovata, Parkinsonia aculeatat, Vallesia pubescens, and Waltheria reticulata forma intermedia are also found. In addition to these a considerable number of herbaceous plants occur among which are: Abutilon crispum, Aristida suspicata, Bidens refracta, Cyperus Mutisii, and Tetramerium hispidum. The sides of the eraters are rather steep and support a more open vegetation than the valleys surrounding them. Plants which commonly occur on the sides of these craters are: Acacia macracantha, Chiococca alba, Scalesia affinis, and S. villosa. The interior of some of these craters were filled with a heavy growth of Parikinsonia aculeata. No ferns or other distinctly mesophytic plants were found on this side of the island, to an elevation of $700 \mathrm{ft}$., as high as it was explored.

\section{Chatham Island.}

Chatham is the most eastern island of the group. It is the fifth in size, being exceeded in this respect by Albemarle, Indefatizable, Narborough, and James Islands. It is twenty-three miles long and about ten miles broad, the greatest diameter of which extends northeast and southwest. Geologically the island is probably very old as there are few evidences of recent volcanic activity, except in the vicinity of Sappho Cove, on the west side. of the island.

The southern part of the island is most visited as there is a settlement located several miles inland, from which has a good wagon road leads down to Wreck Bay. This part of the island is rather flat for some distance inland, and is covered with a considerable amount of soil through which lava boulders project. There are several low lava hills on this part. The northeastern and eastern parts of the island were not visited, but a general survey of these was made from the vessel, and from higher parts 
in the interiol of the island. The region around Terrapin Road, and tor a considerable distance south, is covered by a broad plain which slopes gradually upward towards the southwest. There are several steep hills on this portion of the island some of which probably rise to a height of $500 \mathrm{ft}$. The color and general appearance of these hills indicated that they were composed of tufa. This part of the island is covered with forests, apparently macle up of the forms usually found on the dryer parts of these islands.

There is a strip of country south of the wooded arear which is eovered with beds of basaltic lava on which there is apparently little or no regetation. This is followed on the southwest by still another area covered with vegetation, which extends down to within possibly three miles of Finger Point. East and south of Finger Point the country is again covered with lava, a portion of which is evidently volcanic cinders. There are many small craters on the lava in this vicinity, fifty of which were counted while sailing past this part of the island.

The country around the northeastern end of the island, and for some distance southwest along the east coast, is apparently very similar to that around Terrapin Road. We did not get very close to this part of the island so no very exact observations could be made of its close features. The country around Fresh Water Bay, on the south side, is quite steep and is heavily covered with dark green vegetation well down towards the shore. A stream of water is said to enter the sea at Fresh Water Bay, but as there is no good anchorage here it was not visited.

The interior part of the southern half of the island is a broad plateau which varies in elevation from $900-1,600 \mathrm{ft}$. The plateau is rolling and there are numeros small ravines which have streams of water in them during a part of the year. Small marshes are formed in some of the lower places in this region during the rainy season, but they quickly dry up soon after the dry season sets in again. The main central mountain rises to a height of $2,100 \mathrm{ft}$. and is composed of bits of rolcanic cinders and other fragmentary material all of which is very much decomposed. There is no indication of a crater here, the mountain apparently being a huge pile of volcanic debris. A small crater lake is located on this plateau but was not visited for botanical purposes.

This island is probably better watered than any other one of 
the group. There are several large springs on the plateau, the water from which is piped down to the settlement, located at an elevation of $900 \mathrm{ft}$. Sufficient water is obtained in this way to supply a settlement of about four hundred and fifty people, and to run a large sugar mill. Streams also occur on the lower parts in the vicinity of Wreck Bay, during the rainy season, some of which have a considerable amount of water in them at times. The plateau is covered with a heavy coating of yellow clay-like soil which is mixed with vegetable mold in the wooded areas. This island was visited from Basso Point, Sapho Cove, and Wreck Bay.

\section{Basso Point.}

Basso Point is on the west side of the island about five miles northeast of Wreck Bay. The point shelter's a broad bay which lies southwest of it, around which there are sand beaches and rocky shore. The sand beaches support a few halophytic plants and in the immediate vicinity of these beaches there are thickets of bushes of Cryptocarpus pyriformis, Discaria pauciflora, and Maytenus obovata. The country in the interior is quite rough and there are many exposures of lava on which there is scarcely any vegetation. The country rises gradually to an elevation of about 1,100 ft. above which the ascent is more abrupt, leading up to the top of a range of hills which run parallel with the coasi in a northeasternly direction.

There are low dense forests on this part of the island which are made up mostly of trees of Bursera graveolens and Piscidia Erythrina, both of which are smaller than they are in the regiou around Wreck Bay. There is not as much cactus here as is usually the case in the lower regions. Cereus galapagensis occurs to some extent near the shore but no specimens of Opuntia were seen below an elevation of $800 \mathrm{ft}$., and they were not abundant even there.

There is a heary growth of bushes in the forest in most places the most common species of which are: Croton Scoulera var. albescens, Discaria pauciflora, Gossypium barbadense, and Lantana peduncularis. The Discaria bushes grow so thickly in places as to form impassable barriers by the interlocking of their thorny branches.

This part of the island was not visited above an elevation of $900 \mathrm{ft}$. With the exception of a few specimens of Polypodium 
squamatum, all of the other plants which oceur at this elevation grow abundantly lower down. Apparently the same sort of vegetation continues to the base of the hills mentioned above, about $200 \mathrm{ft}$. higher. The northwest sides of these hills are covered with forests, apparently made up largely of Scalesia trees. The southeast sides are treeless, however, as was noticed from the settlement near. Wreck Bay, later in the season.

\section{Sappho Cove.}

Sappho Cove is also situated on the west side of the island about four miles northeast of Basso Point. The bay is small and almost entirely land-locked, but owing to the fact that it is very shallow, only small vessels can anchor in it. The shores surrounding the bay are made up of basaltic lava and sand beaches on which there are small groves of trees of Rhizophora Mangle and thickets of Laguncularia bushes in places. A short distance back of the beach in the vicinity of salt water pools, there are trees of Avicennia officinalis. The sand in the vicinity of the pools, and on the beaches, is covered in places with a heavy growth of Batis maritima, Sesuvium Portulacastrum, and Sporooblus virginicus. In several places along the open coast, in this vicinity, the sand has been thrown up into long ridges, as a result of the action of wind and waves. These ridges are covered, on the side next to the land, with a heavy growth of Conocarpus erectus, Cryptocarpus pyriformis, Discaria pauciflora, Maytenus obovata, Seaevola Plumieri, and Vallesia glabra. The roots of these bushes prevent the sand from shifting inland too rapidly.

The country is very flat between Finger Point and Sappho Cove, and is eovered with beds of basaltic lava. In the immediate vicinity of the cove this lava is covered with a tolerably dense growth of xerophytic vegetation which gradually becomes thinner farther north until it is practically bare in the vicinity of Finger Point. As the regetation decreases in amount it also becomes smaller, and such species as Bursera graveolens, which grow to the size of trees around Sapho Cove and further south, are mere bushes as Finger Point is approached. This place illustrates the gradual invasion of lava by higher plant life better than any other visted upon the islands. The most common plants on the lava beds here are: Aristida subspicata, Borreria 
ericaefolia, Bursera graveolens, Cardiospermum corindum, Cassia picta, Cereus galapagensis, Coldenia Darwini, Cordia galapagensis, C. lutea, Cryptocarpus pyriformis, Discaria pauciflora Euphorbia articulata, E. viminea forma chathamensis, Gossypium barbadense, Lycopersicum esculentum var. minor, Mollugo gracillima, Pectis tenuifolia, Phoradendron Henslovii, Polygalla galapagensis var. insularis, Porophyllum ellipticum, Scalesia divisa, Tephrosia cinera, and Waltheria reticulata forma intermedia. All of these plants grow from the erevices of the lava in which there is usually no appearance of soil at the surface.

The country south of Sappho Cove is covered with much older lava than is the country north. This lava is very rough in places and has deep fissures in it. The lower parts here are covered with a dense growth of xerophytic vegetation, very similar to that found in the vicinity of Basso Point, except that many trees of Hippomane Mancinella are found around an elevation of $500 \mathrm{ft}$. These trees usually grow along what appeared to be an old stream bed, as there were water-worn boulders in it. There are several small craters near an elevation of $800 \mathrm{ft}$., covered with forests of Bursera graveolens, on which there was an abundance of fruticose lichen.

\section{Wreck Bay.}

Wreck Bay is a rather open sheet of water, somewhat protected by reefs, which is situated at the southwest end of the island, and is the port for the settlement in the interior. The shores around the bay are composed of steep sand beaches, and low cliffs of lava. The country is low for some distance back of the shore, and it is probably of marine origin. There is a moderately steep ascent at the end of the flat area near the shore, which leads up to a broad plain, covered with masses of lava and soil which slopes gradually upward towards the interior to an elevation of $500 \mathrm{ft}$. There are a few small lava hills and craters at various places on this plain. There is rather a steep slope from 500-800 ft. elevation which leads up on to the rolling plateau region covering the central portion of this end of the island.

The settlement is located on this plateau at an elevation of 900 ft. There is a considerable amount of land under cultivation surrounding the settlement, on which coffee, and sugar-cane are produced. There is also a large garden in which many of the 20-S. A. 
common regetables and tropical fruits are grown. The products of the settlement are shipped to Gyayaquil, Ecuador, by means of a small schooner which usually makes monthly trips to the mainland. The plateau region has several high hills and craters on it.

There are no distinctly halophytic plants around the bay so far as was observed. The beaches here are too steep and the wave action at times is so strong that such plants would hardly be able to maintain a hold. The flat back of the beach is covered with Prosopis trees and bushes.

The country is covered with low dense forests below an elevation of $600 \mathrm{ft}$., which are made up mostly of trees of, Bursera gravcolens, Piscidia Erythrina, Psidium galapageium and Zanthoxylum Fagara. In many places in the forest there is a dense growth of bushes under the trees, which are mostly of the species usually found on the lower parts. Places occur in the forest, llowever, where the trees are so closely arlanged that there is very little undergrowth. On rocky hills and craters, in the lower part of this region, there is a considerable growth of Cereus galapagensis. In low places along the side of the road leading to the settlement there are also low groves of Hippomane Mancinella trees. On the steep slopes between 600-800 ft. elevation there are fewer trees and more bushes than lower down. The bushes that are commonly found here are: Croton Scouleri var. grandifolius, Clerodondron molle, Lipochaeta laricifolia and Psychotria lufipes. In some places on these hillsides, however, there are small trees of Scalesia pedunculata, and Hippomane Mancinella, the last of which is sometimes covered with Tillandsia insularis. Many of the bushes disappear higher up and those that remain are very much scattered. There is a heavy growth of grasses and sedges in this region consisting of the following species: Cyperus rubiginosus, Digitaria sanguinalis, Leptochloa virgata, Panicum geminatum, Scleria pterota, Setaria setosa, and Stenotaphrum secundatum. Ferns which occur in shady protected places in this region are: Asplenium formosum, A. sulcatum, Doryopteris pedata, and Dryopteris furcata. The plateau region above $800 \mathrm{ft}$. elevation is covered in most places with grasses, the most common species of which is Paspallum conjugatum, while in low and protected places there are a few trees and bushes. In temporary pools of water, formed during the rainy season, such aquatic and semiaquatic plants as Azolla 
caroliniana, Elcocharis capitata, E. fistulosa, Jussiaea repens, Leinna minor, and Polygonum acre are found. There are hedges of coffee and lime trees, near the settlement, and occasionally one of these is found in the open country, probably an escape from cultivation. There are also deep ditches which were evidently dug at an carlier day to take the place of fences. These have become filled in many places with a heavy growth of bushes of Miconia Robinsoniana, and on the moist perpendicular walls of the ditches there are many small ferns.

The plateau rises gradually in a northeasterly direction, attaining an elevation of $1,700 \mathrm{ft}$. at the base of the main mountain. Around the base of this mountain there are extensive brakes of Pteris aquilina var. esculenta, and in protected places, similar brakes of Gleichenia linearis and small trees of Telanthera rugulosa occur. The sides of the main mountain, which rises $400 \mathrm{ft}$. above the plateau, are covered in many places with a heavy growth of Lycopodium clavatum and ferns. On the leeward side of the mountain and other protected places, this growth is 2-3 ft. high, but where exposed to the constant action of the wind, it is usually much lower. Occasional tree ferns, Hemitelia multiflora also occur on the side of the mountain. Other plants common here are: Cyperus grandifolius, Hibiscus diversifolia, and Polygonum galapagense. Exposed places near the top are covered with Sphagnum, while at the top there are a few bushes and ferns. The soil and rocks in this region are covered with lichens, associated with which are large gelatenous masses which are probably Nostoc colonies.

A good general view of the plateau region was obtained from the top of this mountain. Except in ravines and other low places, it is covered with an unbroken stretch of grass-land from the northeast side around to the south side. On the remaining sides there are occasional trees scattered over the grassland.

All of the lower part of the island, that is covered with forests in the vicinity of Wreck Bay, seems to constitute the dry region. This extends up to about $650 \mathrm{ft}$. elevation, above which the transition forms a narrow belt extending to the grassy region which begins at $800 \mathrm{ft}$. elevation. The transition region here is more of a transition from woodland to grassland than from a xerophytic to a mesophytic regetation. The moist region is apparently not well represented here unless we accept certain small areas, where local conditions are such as to permit a heavier growth of vegetation, as representing this region. 


\section{Culpepper Island.}

Culpepper is located farther north than any other island in the group, and it is also one of the smaller of the islands. Deposits of basaltic lava, and tufa make up the island and form perpendicular eliffs along its sides. The eliffs descend directly into the sea and render landing impossible except at one place on the north side where they have become broken down and formed a large mass of talus. A gently rounded plateau covers the unper part of the island and has an elevation of several hundred feet. This plateau is inaccessible but is heavily covered with vegetation, which appeared from the vessel to be composed mostly of Bursera trees and Croton bushes. In addition to the above, there are a considerable number of small bushes, very similar in size and appearance to Scalesia Snodgrassii, which occurs on Wenman Island about twenty miles to the southeast. Thickets of a species of low Opuntia also occur here. On the talus slope, near the landing place on the north side, a few bushes, of Croton Scouleri var. brevifolins, and Telanthera Helleri occur. Bright red patches of vegetation were seen at various places along the sides of the cliffs a short distance above the water. These are probably composed of Sesuvium Edmonstonei as it forms similar patches elsewhere. One member of the party reported having seen the remains of sedges, the first time that these plants have been reported from this island.

\section{DaphNe Island.}

Daphne Island is a small tufa crater, about half a mile in diameter, and $200 \mathrm{ft}$. high, which is located five miles north of Indefatigable Island. The sides of the island are steep, and with the exception of a few small trees of Bursera graveolens, there is but very little vegetation on them. The only plants collected here were: Abutilon crispum, Euphorbia amplexicaule, and Tribulus cistoides, all of which were taken by Mr. F. X. Williams from the inside of the crater.

\section{DunCAN ISLAND.}

Duncan is a small island, about three miles in diameter, which lies between Albemarle and Indefatigable Islands. The shores are steep and are made up of tall cliffs on all sides but the north 
and northeast. There is a small cove on the northeast side, sheltered by a small islet, which affords a good landing place for boats. Good anchorage can be obtained off the mouth of this cove, but as none is marked on the charts of these islands, vessels should take soundings from a small boat before attempting to come to anchor here.

The sides of the island are steep in most places, and all of the lower part is covered with loose fragments of lava among which there is a scanty soil. There are two old craters in the central part of the island which directly join one another there being no distinct rim separating the two. The crater to the north is the smaller, and its side walls are very steep and redish in color as is the soil which covers its floor. The southern crater forms a broad basin the floor of which is $850 \mathrm{ft}$. above sea level, and 400 ft. above the floor of the northern crater. There are some irregularities in the floor of the larger crater, but the most of it forms a rather flat plain, with occasional low places in it, some of which appeared to have been recently filled with water. There is a considerable amount of soil in this crater, which is light gray in color and loose in texture.

There is a high ridge to the east of the larger crater which in one place attains an elevation of $1,300 \mathrm{ft}$., the lighest point on the island. The west side of this ridge is steep and there are cliffs in some places of a considerable height. The east side of this ridge is not so steep, however, but slopes downward to the tops of the cliffs along the eastern shore of the island. The upper part of this idge is irregular and is covered with soil in places made up of disintegrated lava and vegetable mold.

Halophytic plants are but poorly represented on the island, and so far as was observed, consist of a single tree of Avicennia officinalis, a few Laguncularia bushes, and a few small stunted trees of Rhizophora Mangle, all of which grow at the end of the cove on the northeast side of the island. Sesuvium Edmonstonei also occurs here but not under halophyitc conditions. It is: found in various places on the northeast side of the island to an. elevation of $450 \mathrm{ft}$.

Unfortunately we were not able to get to this island during the rainy season, so at the times we visited here the vegetation was in the resting condition. The lower parts had more the appearance of a winter landscape in temperate region than that of a region within only a few miles of the equator. With the ex- 
ception of the few mangroves, which grow near the shore, there was no other green vegetation worth mentioning. There were no trees of any kind, even the Bursera trees, which occur so abundantly in dry places on the most of the other islands, were entirely absent. This part of the island is covered with open thickets of bushes consisting of Cordia lutea, Gossypium barbadense, Lantana peduncularis, and Prosopis dulcis. Opuntia galapageia occurs abundantly above $450 \mathrm{ft}$. elevation, on the northeast side, but it appears to be almost absent from the north side. The branches of this species are more loosely arranged than usual, and the plants have a rather sickly stunted appearance. Those which occur high up on the island are often heavily covered with fruticose lichens as is the most of the other vegetation in this region. The vegetation thickens up considerably around $500 \mathrm{ft}$. elevation, on the north and northeast sides, and consists mostly of Croton bushes.

The east side of the island is very rough and covered in places with long ridges of rough broken lava, many of which extend down nearly to the tops of the cliffs above the sea. The vegetation on these parts consists mostly of Croton and Prosopis bushes to an elevation of $750 \mathrm{ft}$. Above this elevation the vegetation is more open, however, and there are areas which are covered with small plants, and occasional bushes of Acacia macracantha, Prosopis dulcis, and Zanthoxylum Fagara. The south sides of many of the large lava boulders in this region are covered with Polypodium squamatum, while the north sides are bare. This is probably due to the fact that the south sides of these boulders are bathed by the moist winds during several months of the year, while the north sides are not. The south side of the island was not visited but from a high point it appeared to be covered with a dense growth of bushes, many of which were covered with a brown colored epiphyte, probably a species of Frullania.

The interior of the smaller ef the two craters was not risied, but the inner walls appared to be covered with Croton and other bushes, all of which were heavily covered with lichens. The floor had a few bushes on it but the growth is not heavy enough to hide the soil in most places. The floor of the larger crater, to the south of the smaller one, is sparingly covered with Opuntia galapageia, and bushes of Prosopis dulcis, and Zanthoxylum. Fagara. In low places around dried pools there was an abun- 
dant remains of Cyperus rubiginosus. The inner side of the ridge, to the east of this crater, is covered with a dense growth of Zanthoxylum and other bushes all of which werc covered with lichens and leafy Hepaties. Along the top of this ridge, above an elevation of 1,200 ft., there were bushes and small trees of Acnistus ellipticus, Chiococca alba, Croton Scouleri var. brevifolius, Erigeron tenuifolius, Pisonia floribunda, Scalesia Baurii, Tournefortia psilostachya, T. Pubescens, and Zanthoxylum Fagara. Exposed rocks in this region are often covered with a thick growth of ferns which have formed a considerable amount of vegetable mold upon them. Tillandsia insularis, and two epiphytic species of ferns, Polypodium lanceolatum, and P. lepidopteris occur to some extent upon the bushes in this region. Several grassy areas extend down the east side from the top of this ridge on which there are also small specimens of Opuntia galapageia.

No large trees occur around the top of this island, although Pisonia floribunda, and Zanthoxylum Fagara, which grow here, usually attain the size of large trees at similar elevations on the other islands where these species occur. The absence of large trees is probably due to the strong winds which strike the top of the island during a greater part of the year, and thus prevent the growth of large vegetation.

Botanical regions are not well marked here but practically all of the plants which occur below an elevation of $900 \mathrm{ft}$. are forms typical of the dry regions, above this elevation many of the plants commonly found in the transition region make their appearance.

\section{Gardner Island, Near Charles Island.}

This island is situated about four miles off the east side of Charles Island. It is the smaller one of the two Gardner Islands, which occur in this group, and consists of an immense mass of lava several hundred feet high. The shores are steep in most places and are made up of tall cliffs some of which are perpendicular. Landing is dangerous, and can only be done with safety when the surrounding water is comparatively still.

The writer did not land upon this island so that the only plants collected were by other members of the party. They are few in number and in no way represent the entire flora. The island appeared from the ressel to be covered with low bushes 
which had a grayish color similar to those found on the lower parts of the most of the other islands. There were many specimens of a low species of Opuntia. Lichens seemed to be abundant on the vegetation.

\section{Gardner Island, Near Hood Island.}

This one of the Gardner Islands is situated about a mile off the north shore of Hood Island. The water in Gardner Bay, between the two islands, is quite shallow, so it is likely that the two islands have been connected at some past time. The island is quite small, and is made up of very old lava, some of which has broken down in places forming a light covering of soil mixed with small lava fragments. The east and south sides are rather flat and sand beaches occur along the shores on these sides. The remainder of the island is rough, however, and the shores are bordered by tall cliffs. A small bay is surrounded by these on the north side.

Low bushes of Cryptocarpus pyriformi oceur in several places near the shore. The only trees on the island are those of Bursera graveolens and Opuntia galapageia. Bushes of Cordia lutea, Lantana peduncularis, and Prosopis dulcis are quite com. mon.

\section{HOOD IsLand.}

Hood is the most southern island of the group, being located five miles further south than Charles Island, thirty-six miles west of it. It is also one of the smaller and lower of the islands as its greater diameter is about eight miles and its highest point has an elevation of $640 \mathrm{ft}$. So far as was observed, the shores are high and rocky on all sides but the northeast where there are long stretches of sand-beach and low rocky shore. The sides slope up gradually from the shore at Gardner Bay, to a somewhat flat central region on which there are several rocky hills, some of which rise possibly a hundred feet above the surrounding country. There is no distinct erater on this island. There is, however, a broad flat plain, about half a mile south of Gardner Bay, which may be the floor of a crater, the surrounding hills being all that is left of the rim.

The highest point is towards the southwest side of the island, and consist of a flat-topped hill of lava. A considerable amount 
of soil occurs in various places which has resulted from the breaking down of the lava. The most of the soil has probably been washed from above as it usually occurs in low places. The most of the isalnd has but very little soil on it, and the surface is strewn with fragments of lava.

The beaches are rather steep here in consequence of which there is not a great amount of halophytic vegetation. Bushes of Cryptocarpus pyriformis occur on the sand beaches, and at various other places near the shore. Patches of these bushes form about the only green vegetation during the greater part of the year, and they stand out sharply when the island is examined from the top of one of the hills in the interior. Sesuvium Edmonstonei grows here but usually not under halophytic conditions. The mangrove vegetation is confined to a small thicket of bushes of Rhizophora Mangle which occur on the northeast side of the island below Gardner Bay. The beach, in the vicinity of these mangroves, was strewn with pieces of bamboo, cocoanut husks, and other drift, showing that this area receives a more or less constant supply of such material.

Other plants which occur on or near the beaches are: Cacabus Miersii, Cenchrus distichophyllus, Coldenia fusca, Discaria pauciflora, Maytenus obovata, and Vallesia glabra.

The only trees of any size on the island are those of Bursera graveolens and Opuntia galapageia. The Opuntias have rather low thick trunks and closely arranged branches. Goats, which have been introduced upon this island within the last few years, eat off all of the lower Opuntia branches, and they even eat into the thick trunks in some instances. As these plants form their only suitable food and probably their only source of water, for several months of the year, there is danger of this species being exterminated on this island in time.

The most of the vegetation on the island consists of bushes, the most common of which are: Acacia macracantha, which forms small trees in protected places, Cordia lutea, Croton Scouleri, Gossypium barbadense, Lantana peduncularis, Parkinsonia aculeata, and Prosopis dulcis. These bushes occur in patches in many places in between which there are open spaces which are probably covered with grasses and annual herbaceous plants during the rainy season. By following these open spaces one can travel over the most of the island without much difficulty.

There are some indications of a greater amount of moisture 
around $600 \mathrm{ft}$. than lower down, as Polypodium squamatum grows from the lava crevices at this elevation. There are also a considerable number of small trees of Zanthoxylum Fagara in this vicinity which is near the base of the high hill on the southwest side of the island. The top of this hill is covered with bushes of Cordia galapagensis, Cryptocarpus pyriformis, Lycium geniculatum, Tournefortia psilostachya, and Vallesia glabra. Ipomoea Habeliana covers the rocks here to a considerable extent.

\section{INDEFATIGABLE ISLAND.}

Indefatigable is the second largest, and with the exception of Duncan, is the most centrally located island in the group. It is roughly circular in ontline, and appears to have a large central crater when seen from the south side. There is probably no larger crater present, however, because in sailing around the island towards the west side it is seen that the upper part is covered with many small craters, twenty-one of which were counted. Small lateral craters also occur at various places along the sides, the largest one of which is on the southeast side of the mountain a short distance below the top.

The shores along the south, southeast, and east sides of the island are bordered by low rocky cliffs of lava in most places, while on the other sides the shores are low with occasional sand beaches. There is a large bay on the south side which we christened it Academy Bay in honor of the California Academy of Sciences.

The sides of the island slope up very gradually on all sides so that it is necessary for one to travel several miles inland in order to get into the region where collecting is good. All of the lower parts are covered with the usual xerophytic forms so common on these islands, but which are not in proper condition for collecting through a greater part of the year. The lower parts are covered with lava on which there is but little soil, but in the interior there is an abundant soil, and in places there is said to be water, although we were not fortunate enough to find it. The interior of this island is very fertile, and with proper cultivation is capable of supporting quite a large population, but up to the time we visited it no attempt had been made to establish a settlement there.

We visited the island at Academy Bay, at two places on the 
north side, the northeast side, the northwest side at a point a little south of Conway Bay, and on the southeast side.

\section{Academ.y Bay.}

Academy Bay is a small body of water, partly surrounded by cliffs, on the south side of the island. It is marked by a small islet which lies on the east side of the entrance. Small vessels ean find good anchorage in this bay but care shonld be taken in anchoring in the western part of it as there are hidden rocks present there. This part of the bay is the best protected from the sontheast swell, so we anchored there on our first visit to this place, and were unfortunate enough to get aground on two occasions. The best landing place for boats is at the north end of the bay where there is a small sand beach, and a low flat area covered with bushes and grass, back of which there is an old trail leading into the interior. Two springs of brackish water occur here, each of which are marked by a bunch of small trees of Hibiscus tiliaceus. The country is very rough for a mile or more back from the beach and is covered with low ridges of lava, many of which run in a direction nearly parallel with the coast line. There are also many crevices in this lava, some of which are evidently quite deep. The lava has disintegrated but little on this part so there is very little soil to be seen on the surface, but nevertheless it is heavily covered with vegetation.

To the north of the rough area just mentioned, there is a line of eliffs, about $75 \mathrm{ft}$. high, above which the lava is evidently much older, as it has broken down in many places into soil, through which boulders of lava protrude at intervals. The amount of soil increases farther inland, completely covering the lava in most places above an elevation of $500 \mathrm{ft}$. The soil at this elevation, and above, is composed largely of vegetable mold which has been formed from the decay of the abundant vegetation in this region.

Small swamps of Rhizophora Mangle occur at several places around the shores of Academy Bay and around a small lagoon which empties into it. There are also clumps of Laguncularia bushes along the shore, and oceasional trees of Avicennia officinalis around salt water pools in the vicinity of the shore. Back of the beach, at the north end of the bay, there is a small area that is thickly earpeted with Sporobolus virginicus. Thickets 
of Cryptocarpus bushes also occur here covered with Passiflora foetida. Oceasional trees of Hippomane Mancinella also grow on this area. In many places along the west and south sides of the bay the growth consists of low bushes, with a considerable number of Cereus sclerocarpus and Opuntia myriacantha trees scattercd among them.

After leaving the immediate vicinity of the shore, at the north end of the bay, one encounters dense jungles of xerophytic plants which extend inland a mile or more to the base of the cliffs mentioned above. This jungle is composed largely of trees of Acacia macracantha, Bursera graveolens, Erythrina velutina, Opuntia myriacantha, and Piscidia Erythrina. The specimens of Opuntia are very large, some of them attaining a height of thirty or more feet. In general it may be said, that nearly all of the species which occur in this area either attain a larger size, or grow more abundantly than they usually do so near to sea level. There is a dense growth of bushes underneath the trees consisting of Cordia lutea, Croton Scouleri varieties, brevifolius and Macraei, Discaria pauciflora, Gossypium barbadense, Lantana peduncularis, Maytenus obovata, Parkinsonia aculeata, Prosopis dulcis, Scalesia gummifera, Telanthera echinocephala, Tournefortia pubescens, and Zanthoxylum Fagara. Such ferns as Polypodium squamatum and Trachypteris pinnata grow on the sides of the cliffs at an elevation of $75 \mathrm{ft}$. Above these cliffs there is a considerable area which is covered with Prosopis and other bushes of an xerophytic character, but the arrangement of these is more open than below the cliffs. The trees of Opuntia myriacantha are numerous and very large in this area, and form a portion of the continuous zone of Opuntia trees which extend around the south side of the island. They are so numerous here that their redish-brown trunks give this color to the surrounding landscape when seen from a distance.

There is a general thickening up of the vegetation further inland, but there is not much change in the species of plants present below $350 \mathrm{ft}$. Around this elevation such forms as Cordia lutea, Croton Scouleri var. brevifolius, Discaria pauciflora, Opuntia myriacantha, Parkinsonia aculeata, Piscidia Erythrina, Prosopis dulcis, and Telanthera echinocephala disappear. The most of the vegetation, around this elevation, is heavily covered with fruticose lichens. There are dense forests here made up largely of trees of Pisonia floribunda, Scalesia pedunculata, and 
Zanthoxylum Fagara, the first and last of which occur near the shore as bushes. The trees are often eovered with a heavy growth of Cisampelos Pareira, which usually put down large numbers of aerial roots, forming tangled masses, rendering traveling difficult. Projecting ridges of lava occur in some places in this region, which are usually covered with dense mats of Polypodium squamatum, ands such herbaceous plants as Peperomia galioides, P. galapagensis, P. Stewarti, and other forms. The trunks and branches of many of the trees, especially those of Pisonia floribunda, are heavily covered with epiphytic plants such species as: Asplenium sulcatum, Ionopsis utricularioides, Lycopodium dichotomum, Polypodium lanceolatum, P. lepidopteris, Peperomia galapagensis, and Tillandsia insularis being the most common. Phoradendron Henslovii also occurs in this region and higher up, but it grows much larger than it does lower down. Owing to the dense shade there are fewer bushes, but more herbaceous forms than at a lower altitude. Ferns are also common.

The region above an elevation of $500 \mathrm{ft}$. on this side of the island consists of two distinct parts as far as the vegetation is concerned. The country immediately north of Academy Bay, above this elevation, is covered with dense forests which extend towards the east side of the island. In some places north of Academy Bay these forests probably begin a little lower down, but farther east they evidently begin somewhat higher, as they were not encountered at an elevation of $650 \mathrm{ft}$. when the southeast side of the island was visited. It might be said in this connection, that all of the botanical regions gradually ascend towards the east side of the island here, a condition which can be readily seen from the shore by the difference in color of the different regions. The forests, just mentioned, were not visited but from their appearance they must be made up largely of trees of Scalesia pednculata, and other species common in the Scalesia forests of these islands. Northwest of Academy Bay there are extensive areas covered with bushes on which there is a heavy growth of Argyreia tiliaefolia and other vines. The vegetation in this region was denser than in any other place visited upon the islands. Traveling was very slow and difficult here it being necessary at times to lift one member of the party up and let him fall at full length into the bushes and other vegetation in order to mash them down, for it was almost impossible to cut one's way through this vegetation, loaded down with water and food 
as we were. 'The principal bushes in this region are: Psychotria rufipes, Tournefortia rufo-sericea, Urera alceaefolia, and some other's, the time spent in this region not being sufficient to make as complete collections as was desirable. There are many ferns. and herbaceous plants in this region. Many of the herbaceous forms which occur here also occur lower down but are much smaller in size. The most noteworthy of these are: Crotalaria setifera and Fleurya aestuans, the last of whieh has fewer stinging hairs than at the lower elevations where it occurs. Groves. oceur oceasionally in the bushy areas, made up of the trees usually found in the moist regions. Some of these groves are quite large, but usually they are small. Isolated trees are not at all uncommon.

No plants were collected above an elevation of $650 \mathrm{ft}$. on this side of the island, but other members of the party who succeeded in getting farther inland, report that there is a decrease in the number of vines and an increase in the size of the bushes higher up. Messr's. Williams, Ochsner, and Gifford sueeceded in reaching all elevation of $1,100 \mathrm{ft}$. here, reported that the country, a short distance beyond where ther discontinued their journey, appeared to be covered with low spreading trees or bushes on which there was a large amount of "brown moss." A large part of the country, above the Scalesia forests, and bush areas, had a distinctly brown eolor in which there are patches of green. The brown color is possibly due to a heavy growth of one or several species of leafy Hepatics, and is eonfined to the south side of the island, none of it appearing on the other sides. The top of the mountain is eovered with green vegetation, but it is likely that there are no trees present there, beeause none appeared in the sky-line when the top of the mountain was viewed with a field glass on a elear day.

As near as could be ascertained, the dry region extends to an elevation of about $350 \mathrm{ft}$., the transition region to $500 \mathrm{ft}$. while it is likely that the moist region extends to at least $1,500 \mathrm{ft}$. and possibly higher.

Judging from the appearance, the upper part of this island ought to be very interesting botanically, as it is apparently entirely different from the upper part of any other island visited.

It would probably require a week or more to explore this region properly, and in order to do this, it would be necessary to cut a good trail into the interior, and a camp established, where 
supplies of food and water could be brought in each day. It would probably be more economical to have this work done by laborers, as they could probably be secured from Albemarle Island at a small cost. Unfortunately our expedition was not financed in a way to make this possible.

\section{Southeast Side.}

The place visited on this side of the island, is situated about seven miles east of Academy Bay, the region just described. It is dangerous for vessels to anchor here, except during calm weather, as there is a strong swell at other times. We visited this place during the month of October, and were greatly inconvenienced by the violent rocking of the vessel at times. There are several hidden reefs between the anchorage and the shore, on which the swell breaks heavily at times. One has to use care in going in and out in a small boat when there is even a slight swell, because it is liable to break in unexpected places. A small crater stands near the shore at this place. Broad sand beaches border the shore, back of which there is a sandy basin containing pools of brackish water. There is supposed to be fresh water in this vicinity but we were unable to find it.

With the exception of a few ravines in the vicinity of the shore, the country is comparatively smooth for some distance inland, and is covered with a fair amount of soil. Farther inland, above an elevation of $200 \mathrm{ft}$., there are beds of more recent lava which has been piled up in places forming low ridges and valleys. Several small craters are located about four miles inland, between 400 and $500 \mathrm{ft}$. elevation, which rise on an average of about $100 \mathrm{ft}$. above the surrounding country. The country to the right of these craters is rough and covered with irregular masses of lava, while to the left it is comparatively smooth. The country was not visited beyond these craters, but it appeared from the top of the one fartherest inland, to have no. pronounced irregularities in it as it sloped gradually up to the base of the craters in the central part of the island.

Rhizophora Mangle occurs in isolated patches along the shore, but there are no large swamps of it, probably due to the fact that the surf breaks here much of the time. Quite a number of other species of plants grow on the beaches among which are Coldenia Darwini, Cryptocarpus pyriformis, Heliotropium cur- 
assavicum, Scacrola Plumieri, Sesuvium Portulacastrum, and Vallesia glabra. The low sandy area back of the beach is covered in some places with a heavy growth of Sporobolus virginicus, while in other places, where the sand is enerusted with salt, I pomoea Pes-caprae grows very abundantly and of great length, individual plants sometimes being fully one hundred feet long. Cyperus lacvigatus is very common around the pools of brackish water, which have a strong odor of Sulphurated Hydrogen. Bordering this sandy area are low dense groves of Avicennia offcinalis, Hippomane Mancinclla, and Laguncularia racemosa. There are several other low areas and ravines in the vicinity of the shore, above high tide mark, which are filled with thiekets of Discaria pauciflora, and Parkinsonia aculeata. The remainder of the lower part of the island at this place is covered with bushes, Burscra trees, and cactus. Cereus sclerocarpus occurs commonly in the vicinity of the shore but was not seen above an elevation of $100 \mathrm{ft}$. Opuntia myriacantha, on the other hand, oecurs abundantly on the lower parts, and to a considerable extent to about $500 \mathrm{ft}$. At an elevation of $600 \mathrm{ft}$., however, it is scarce, and much smaller than lower down. The specimens seen at this elevation, were of about the same size as those which occur at an elevation of $350 \mathrm{ft}$. at Aeademy Bay a few miles west of here. The Bursera trees are larger and more abundant above an elevation of $350 \mathrm{ft}$. than they are lower down. They are usually heavily covered with fruticose lichens. Piscidia Erythrina is another common forest tree in this region.

There is a very noticeable decrease in the number of many of the forms common on the lower parts, between 350 and 450 ft. elevation. Some of the species disappear here among which are: Croton Scouleri, Discaria pauciflora, Maytenus obovata, and Telanthera echinocephala. A few stunted specimen of Cheilanthes microphylla were found in the lava crevices at an elevation of $350 \mathrm{ft}$, and were the first ferns ever collected on this island.

There are fewer trees in the region of the craters, at $400 \mathrm{ft}$., elevation, than lower down, and the country is covered with Lantana bushes four to five feet high with a few trees seattered through them. The sides of the craters are covered with low bushes of Euphorbia viminea, and other species, while at the top there are bushes, ferns, and grasses. The country to the north of these craters, is heavily forested with Bursera and 
other trees, under which there are tangled thickets of Zanthoxylum bushes.

Low forests cover the country between 450 and $650 \mathrm{ft}$. elevation, which are made up of a mixture of xerophytic and mesophytic forms. Bursera trees are common on the lower part of this area, but they decrease in number higher up, where the forests are composed largely of Pisonia floribunda, Psidium galapageium, and Scalesia pedunculata. The Scalesia trees are smaller, and fewer in number here than they are in the Scalesia forests higher up. Quite a number of ferns grow in the vegetable mold, and on exposed rocks in this region, such species as Polypodium pectinatum, P. squamatum, and Trachypteris pimnata being the most common. A few epiphytes grow on the trees and bushes among which are: Ionopsis utrieularioides, Peperomia galapagensis. Polypodium lepidopteris, and Tillandsia insularis. Common bushes in this region are: Chioeocea alba, Erigeron tenuifolius, Gossypium barbadense, and Tournefortia strigosa. The region above an elevation of 650 ft. was not visited, but it appeared to be covered with Scalesia forests a short distance above this elevation.

The dry region extends to an elevation of about $400 \mathrm{ft}$. at this place. We did not reach the upper limit of the transition region, but as near as could be estimated, it extends to about $800 \mathrm{ft}$., the elevation at which the Sealesia forests probably begin.

No effort was made to get far into the interior at this place, as we made our first visit to the island here, and expected to find better places for doing this elsewhere later in our trip. After having failed to accomplish this at other places, it now seems probable that this would have been the best place to have made the attempt after all. It is very likely that one would have no difficulty in reaehing the lower edge of the Scalesia forests in a half day's journey, if no collecting were done on the way. From this point it is probably not over three or four miles to the base of a large lateral crater, on the southeast side of the mountain just below the top. Judging from its appearance, this crater would present about the same botanical conditions as oecur around the top of the mountain. The advantages to be gained from exploring the interior of the island from this side are; the slope is not so gradual, so that elevation could be gained by traveling shorter distances, and. 21-S. \& A. 
there are heavy forests in the moist region which would probably have less undergrowth in them than the bushy areas encountered in this region at Academy Bay. Should another party ever attempt to reach the interior of the island from there, they should keep well to the south of the group of craters, about four miles inland, as the country is not so rough, nor is the vegetation so dense as it is north of these craters. A low monument of lava boulders was built by the side of the trail where we camc into it in coming back from the interior. It is likely, however, that the trail will be entirely obliterated before another party attempts to explore this island.

\section{Northeast Side.}

The island was visited on this side at a point about three miles west of Gordon Rocks which are situated a short distance off shore. The coast is bordered by low cliffs in this vicinity, which rise abruptly fifteen or more feet above the water. There are occasional small sand beaches, however, so that landing from boats can be easily accomplished. The country is very flat for some distance inland, and for the most part, is covered lightly with a reddish colored soil. Farther inland there are rough deposits of lava. We had expected to try to reach the interior of the island from this place,- but we did not attempt it after we had discovered the rough character of the country.

There are no true haloplyytes along the shores in this vicinity, a condition that is accounted for by the lack of extensive sand beaches, such as occur on the other sides of the island where there is a more or less extensive halophytic flora. Such plants as Cryptocarpus, pyriformis, Discaria pauciflora, and Maytenus obovata, which sometime grow under semihalophytic conditions, occur, however, at this place.

The country is very barren in the vicinity of the shore, and there are no trees present unless a few stunted specimens of Bursera, and Prosopis could be called such. The country farther in. land, however, appeared to be covered with forests of Bursera trees, but as we risited this region during the dry season, the general appearance of these forests was too uninviting to tempt one to venture far to examine them. All of the vegetation of any considerable size, leans in a northwestern direction showing the influence of the strong southeast winds during the growing 
season. The strong winds, and the loose character of the soil, are the probable causes for the small amount of vegetation here. The ground in most places is covered with a sparse growth of grass, the two common species of which are, Aristida subspicata, and Panicum hirticaulum.

\section{North Side.}

The shores along the north side of the island are made up of sand beaches and low rocky coast, which in most instances slope down gradually to the edge of the water. There are but few cliffs along the shore on this side, a condition that is probably due to the fact that this is the leeward side of the island and is consequently not subject to strong wave action as are the more exposed sides.

For a considerable distance inland the country is flat and covered in many places by beds of basaltic lava on which there is but little soil. There are small areas, however, which are covered with a light gray ashy soil in among the deposits of lava. Rough lava ridges are common, and there are several low lavahills, and small craters scattered around at various places on this side.

The sand beaches for the most part bear the usual herbaceous plants, and in the vicinity of the shore thickets of Cryptocarpus pyriformis, and Vallesia pubescens bushes are common. Bushes of Maytenus obovata line the shore in places, some of which grow so close to the water's edge that their roots are covered at high tide. In such places the trunks are more gnarled, and the leaves more succulent than is usually the case. Mangrove swamps occur in several places, the largest one being located about two miles west of the lower end of South Seymour Island. So far as was observed this is the most typical mangrove swamp on the islands. A shallow bay occurs here which has a narrow opening into the sea and affords much quieter water than in most places. on these islands. There are several small islets in the bay, and these as well as the shores of the bay are heavily covered with, mangroves. One is able to get through the swamp in a small boat by following the deeper channels at high tide. We found it. to be an excellent place for capturing sea turtles. Trees of Avicennia officinalis and Laguneularia also oceur in this swamp, but: Rhizophora makes up the bulk of the regetation.

All three spe- 
eies occur at various other places along the north shore, and Avi. cenuia was found in one instance to be growing in a sunken place, a short distance inland, which was apparently filled with sea water at high tide.

The interior is barren in many places where there are exposures of lava. With the exception of a few low stunted trees of Bursera graveolens, a low Opuntia, and seattered bushes these beds bear no other vegetation. The species of Opuntia is possibly a new one as it difters quite markedly from the other species in this genus which oecur on these islands. It also oceurs on South Seymour Island, a few miles away, but at neither place were the specimens in good shape at the times these were visited. Occasional bushes of Acacia macracantha, and thiekets of Croton bushes oceur in small patches between the lava beds, where there is a sufficient amount of soil to support them. Grassy areas oceur, between the patehes of bushes, which are usually covered with Aristida subspicata. These areas continue at intervals, to an clevation of $1,000 \mathrm{ft}$. as high as this side of the mountain was explored. Very little change takes place in the character of the vegetation at this elevation, except that some of the species grow to a larger size than they do lower down. This is especially true of Bursera graveolens, and Piseidia Erythrina, both of which are quite small near the shore but form trees in the interior.

The dry region extends to possibly an elevation of $1,500 \mathrm{ft}$. on this side of the mountain, as the appearance of the vegetation did not appear to change for several hundred feet above where exploration was discontinued. The moist region seems to form a narrow zone just below the top on this side of the mountain.

\section{Northu'est Side.}

This side of the island was visited at a place about two miles south of Conway Bay, which is marked by a small tufa erater near the shore. Our reason for stopping here instead of at Conway Bay, the usual place for landing on this part of the island, was because we had learned at Chatham Island that an old trail led into the interior from this point.

The coast is low in this vicinity, and is made up of sand beaches and low cliffs. A flat area surrounds the tufa crater. mentioned above, covered with a soil composed largely of voleanic ashes, which have evidently originated from the crater. This 
condition is local, however, as the most of the soil on the lower parts is eomposed of disintegrated lava with small boulders and bits of lava intermixed. There are also lava ridges in this vicinity without soil.

The slope is very gradual to $700 \mathrm{ft}$. and in places the country is slightly terraced. Above this elevation the ascent is quite steep to $1,000 \mathrm{ft}$. beyond which there is a broad valley, three or four miles wide, extending in to the base of the craters on the west side of the island. There is a heavier growth of vegetation here than on the north side of the island, probably due largely to the fact that there is more soil.

About the only vegetation on the beach, where we landed, was a sparse growth of Sporobolus virginieus, but back of the beach around the base and on the sides of the cliffs there were bushes of Cryptocarpus pyriformis, Discaria pauciflora, and Maytenus obovata. Grassy areas oceur back of the shore, where the soil is composed of ashes, which at the time of our visit were eovered with a heavy growth of Aristida subspicata. There is probably quite a growth of annual plants in addition to the above, during the rainy season, as the remains of quite a number of these were found. Patches of bushes occur in the grassy areas which are made up of such species as Acacia macracantha, Clerodendron molle, Cordia lutea, Croton Scouleri var. brevifolius, Gossypium barbadense, and Waltheria reticulata forma intermedia. Low trees of Bursera graveolens and Piscidia Erythrina occur among the bushes. A few specimens of Opuntia grow in the vicinity of the shore but whether or not these are O. myriaeantha or the undescribed species from the north side of the island, was not determined, as no specimens were collected. They are more abundant farther inland.

The character of the vegetation changes but little to an elevation of $300 \mathrm{ft}$. except that the grassy areas soon stop and the country is covered with Bursera forests very similar to those on the lower parts of other islands. Trees of Erythrina velutina also occur here in considerable number. Cissampelos Pareira appears first at about $300 \mathrm{ft}$. elevation, but it becomes more abundant higher up where it often covers trees and bushes. A few of the more xerophytic species of ferns appear around an elevation of $400 \mathrm{ft}$. We experieneed much difficulty with the thickets of Fureraea eubensis at an elcration of $450 \mathrm{ft}$. and above, as they often cover areas of scvern! acres in extent in this 
region. This spereies was brought to this island many years ago by the tortoise hunters who made a temporary settlenent here, and who introduced it among other domestieated plants. They were planted along the trail, leading into the settlement, by Captain Thomas Lerick of Chatham Island, on one of his periodic visits to this place. He loped to permanently mark the traii by this means, but judging from the diffieulty we had getting around these thickets and finding the trail again, his method of marking it was rather too efiective. They grow so thickly that they have driven out the smaller vegetation in places.

The country around $650 \mathrm{ft}$. elevation is heavily forested with trees of Bursera graveolens, Piscidia Erythrina, Pisonia floribunda, and Zanthoxylum Fagara. This forest is open in places and the ground is covered with oceasional bushes and ferns. Above $700 \mathrm{ft}$. elevation the forms which occur abundantly on the lower parts, disappear. The forests above this are made up of large trees of Pisonia floribunda, Psidium galapageium, Scalesia pedunculata, and Zanthoxylum Fagara, the last of which forms trees 25-30 ft. high, usually heavily corered with mistletoe. The undergrowth is usually dense in these forests and is composed largely of bushes of Erigeron tenuifolius, Psychotria rufipes, Tomrnefortia rufo-sericea, and several speeies of ferns and herbaceous plants. Epiphytes are common, eonsisting of ferns and orehids, Ionopsis utricularioides. Conditions similar to the above, continue to an eleration of $1,000 \mathrm{ft}$. as high as this side of the island was explored. From a tree at this elevation, the country appeared to change but little for several miles further inland.

We visited this place during July, and as it was the last time that we expected to stop on this island, we made a rather determined effort to get farther into the interior than we had done before. We hoped to follow the trail in as far as the old settlement where it is reported that water ean be found, and where there are a number of domestieated plants growing which are suitable for food. We expected to camp at the settlement and try to work inland from there. We lost the trail at 1,000 ft., however. and had to turn back as our supply of food and water was not sufficient to justify us in going farther. The only evidences of former habitation found, was a number of lime trees near where we lost the trail. We learned afterwards that these were but a short distance away from the settlement, but as everything was 
so overgrown with vegetation in this region, it probably would have been impossible for us to have found it unless the trail had led directly to it.

The botanical regions are fairly well marked here. The dry region seems to extend to about $450 \mathrm{ft}$. and the transition region to about $700 \mathrm{ft}$. elevation. The moist region seems to be evenly forested and has none of the open areas corered with bushes and vines, such as was found at Academy Bay on the south side of island.

\section{JAMES ISLAND.}

James, the fourth largest island in the group, is located nine miles northeast of Cowley Bay, Albemarle Island, and twelve mile north by west of Indefatigable Island. The general shape of the island is a parallelogram the length of which is about twenty miles, and extends east and west. With the exception of a few sand beaches, the shores are rocky and are bordered in most places by low cliffs of lava. The eastern part of the island is low, and slopes up gradually to a broad central plateau which extends, with a gentle slope, to the base of the main crater, located towards the west end of the island. This crater has an elevation of 2,850 ft., and can be more easily reached from James Bay than from any other point. Many other eraters occur on the island, but with one or two exceptions, they are all small. There are a number of these in the vicinity of Sullivan Bay, and along the south side. Deposits of basaltic lava, and voleanic cinders, cover the greater part of the island, the most of which is quite old, and has become very much oxidized. In many places in the interior, it has become entirely broken down on the surfaces, into soil, which is mixed with quite a large amount of vegetable mold.There are, however, some very recent deposits of lava on the south side, some of which have recently come from a small crater which has been active within the last few years. Deposits of tufa occur on the west side, but they are very local in their distribution.

\section{Northeast Side.}

This side of the island was visited about six miles northwest of Sullivan Bay. There is a small salt-water lagoon here, apparently the only one on the island. The shores are low and rocky 
in most places in this vicinity, but short sand beaches occur oceasionally. The country is covered with beds of rough basaltic lava and einders all of which is very old and has become stained with a dark brown color. This lava has not become broken down to any extent, so consequently there is but little soil in this region. The ascent is very gradual here so that it is necessary to go about four miles inland in order to reach the plateau region, which covers the central part of the island. 'The eastern part of this plateau has a general elevation of about $700 \mathrm{ft}$., but it slopes up gradually, towards the west, to the base of the mountain. There is more soil on the plateau than lower down, but it is mostly in low places so that the surface of the ground is usually strewn with lava fragments. Several old craters are located on the plateau at an elevation of $700 \mathrm{ft}$., all of which are low in altitude.

The sand beaches support many of the smaller plants which are usually found in such situations on these islands. Among these are: Batis maritima, Cryptocarpus pyriformis, Discaria pauciflora, and Sporobolus virginieus. Rhizophora Mangle is the only one of the mangroves that grows on the open coast at this place. It also grows to some extent around the shores of the salt water lagoon, mingled in places with Avicemnia officinalis. In the vicinity of the shore, the country is covered in places with thickets of Discaria, and Maytenus bushes, but there are no trees except those of Opuntia myriacantha. There are a few specimens of Bursera, but they are mere bushes, and do not grow to the size of a tree for some distance inland. The crowns of the Bursera trees are usually much flattened, due to the action of the wind. There are quite a number of species of bushes farther inland, all of which grow from the erevices of the lava. Among these are: Alternanthera rigida, Cordia lutea, Croton Scouleri var. albescens, Euphorbia articulata, and Scalesia atractyloides. With the exception of the halophytes along the shore, the Scalesia bushes were about the only plants that presented a green appearance at the time of our visit. There were many other plants in leaf at this time, but the leaves were either small, or corered with a dense coating of hairs so that the green color was obscured. There are small stretches of lava near the shore on which there is practically no vegetation.

The vegetation becomes more abundant between 100 and 200 ft. elevation where there are extensive thickets of Lipochaeta 
bushes, which also oceur still higher up on this side of the island. This species is infested with Phoradendron Henslovii as are some other forms in this region and above. The vegetation is further added to, between 300 and $400 \mathrm{ft}$. elevation, by the appearance of small trees of Erythrina velutina, and thickets of Zanthoxylum bushes, the last of which apparently does not attain tree size on this side of the island. Opuntia galapageia occurs in this region and continues to above $700 \mathrm{ft}$. elevation.

The plateau, around $700 \mathrm{ft}$. elevation and above, is covered with much the same sort of vegetation as the lower country, except that it is thicker in places, and some of the species attain a larger size. No ferus or other distinctly mesophytic plants were found if occasional small trees of Pisonia floribunda be expected. The small craters on the plateau are covered with bushes, and trees of Cereus sclerocarpus and Opuntia galapageia all of which have a considerable amount of fruticose lichen on them. A good view of the surrounding country can be had from the tops of these craters. The country to the south and east was barren in the extreme and apperred to be covered with much the same sort of vegetation which occurs in the region explored on the north side of the island. The country to the west appeared almost as uninviting, for possibly $700 \mathrm{ft}$. higher, and the regetation all had the distinctly gray color characteristic of the dry regions of these islands. It was noticed, while we were sailing along the north shore, that similar conditions to the above are present nearly to the top of the mountain on this side.

\section{James: Bay.}

The conditions at James Bay, at the west end of the island, were much more inviting than they were on the northeast side. A sand beach extends along the east side of the bay and affords a good landing place for boats the most of the time. The north side of the bay is bordered by cliffs, which rise in height towards the northwest and terminate in a tall perpendicular cliff about opposite Albany Island, which is situated a short distance off shore. The coast is rocky for some distance south of the bay, and is made of low up cliffs of recent lava. Back of the sand beach, just mentioned, there is a stretch of flat sandy country, in which there is a small salt water lake. The flat country extends to the base of the mountain which rises quite abruptly to an elevation of about $1,400 \mathrm{ft}$., beyond which the slope is more gradual, 
and the country is in the nature of a table land to the base of the main erater at about $2,200 \mathrm{ft}$. elevation. The sides of this crater are steep and the top has an elevation of 2,850 ft. To the south and southwest of the main crater there are deep valleys in between other craters and hills. The whole of the south side of the island is steep, above $900 \mathrm{ft}$. elcvation, for several miles east of James Bar. Below this eleration, however, the slope is more gradual and the country is covered with recent flows of lava, the most of which has probably come from one or more of the small lateral craters around $900 \mathrm{ft}$. elevation. The lava fields are comparatively smooth near the shore, but higher up they become rough, and in places the lava has cooled enclosing gas bubbles with only a thin shell of lava above, through which one breaks in walking.

The region around Sugarloaf mountain, towards the southwest side of the island, is covered with tufaceous deposits, which have probably come from the tufa craters in this vicinity. One of the smaller tufa craters, encloses a salt water lake, on the bottom of which there is a layer of apparently nearly pure salt several inches in thickness. The people from the inhabited islands used to come here for their supplies of salt many years ago.

Except on the recent lava and on the steeper sides of the mountain, there is a considerable amount of soil to be found all over this part of the island. The soil is composed of disintegrated lava, which on the higher parts is mixed with vegetable mold. No springs occur on this island but there are a few small stream beds in the upper region, which appeared to have contained water at some time, as there were water-worn stones and pebbles in them.

There are but few halophytic plants on the sand beaches around James Bay. Batis maritima oceurs in a few places and there is a considerable growth of bushes of Conocarpus erectus bordering the shore. A heary growth of bushes and small trees surrounds the salt-water lake, just back of the beach, which consists of the following species: Aricennia officinalis, Cryptocarpus pyriformis, Discaria pauciflora, and Maytenus obovata. The remainder of the sandy area, at the base of the mountain, is covered with open woodland made up largely of trees of Bursera graveolens, and Erythrina velutina, the last of which were in blossom when we visited this place in December. There are also open grassy areas in the woodland covered mostly with Setaria setosa, bushes of 
Telanthera echinocephala, and Lantana peduncularis. The last one of these also occurs on the north and south sides of the bay, where it often forms dense thickets five or six feet high, covered in shady places with vines of Asclepias angustissima, and Passiflora linearloba.

Except for an occasional bunch of Cereus nesioticus, and a few other plants, all of which occur in protected places, the recent lava beds south of James Bay, are practically bare of vegetation below an elevation of $500 \mathrm{ft}$. Along the edges of these beds, next to the older lava, however, there are thickets of bushes which are made up almost entirely of Scalesia atractyloides, which does not seem to grow in any other situations, here. Borreria ericaefolia is another plant which is found in similar situations to the above, and also for some distance out on the lava beds. Above an elevation of $500 \mathrm{ft}$. there is a considerable amount of small vegetation on the recent lava, made up mostly of Asclepias angustissima, and Polypodium squamatum. This increases in amount with the ascent and at an elevation of 900 ft., there are small trees of Cereus sclerocarpus, and bushes of Dodonaea viscosa, and Lipochaeta larcifolia. Quite a number of ferns are to be found in the old craters and lava caverns around this elevation among which are: Aspleninm, cristatum, A. formosum, A. sulcatum, Ceropteris tartarea, Nephrolepis bisserata, and $\mathrm{N}$. pectinata. Many of the species which were common at a lower elevation, occur along the edges of the recent lava beds here, associated with such mesophytic forms as bushes of Erigeron tenuifolius var. tomentosus, and Psychotria rufipes, and trees of Pisonia floribunda. The presence of ferns and other mesophytic plants associated with such xerophytes as Bursera, and Cereus, indicates that the region around an elevation of $1,000 \mathrm{ft}$., on this side of the island, lies within the transition region.

There are several islands of vegetation on the lower part of the south side of the island which are surrounded by beds of recent lava. None of these were visited, but they appeared from a distance to be covered with the usual species found in the dry regions. Several small mangrove swamps occur along the south shore.

The tufaceous region in the ricinity of the Sugarloaf Mountain is covered with small Bursera trees, Croton bushes, and other dry-region forms. The Sugarloaf mountain is a large tufa 
crater with sieep sides, which rises to a height of $1,200 \mathrm{ft}$. The sides of the mountain are eovered with dry-region forms and apparently there is but little ehange in the character of the vegetation from the bottom to the top. The appearance of the mountain was so uninviting that the top was not visited. The interior of one of the smaller tufa craters in the vicinity of the Sugarloaf was visited, however, and a few halophytic plants, and trees of Hippomane Maneinella were found growing around the salt watel lake in its interior.

The sides of the mountain east of James Bay are eovered with forests, which to an elevation of $1,000 \mathrm{ft}$. are composed largely of trees of Acacia tortuosa, Bursera graveolens, Erythrina velutina, and a few trees of IIippomane Mancinella. The undergrowth is usually jather open in this region and is made up mostly of bushes of, Castela galapageia, Cordia lutea, Croton Scouleri var. brevifolius, Telanthera echinocephala, Tournefortia strigosa, and Waltheria retieulata forma intermedia. Occasional trees of Sealesia peduneulata begin to appear around an elevation of $1,000 \mathrm{ft}$., but they become larger and more abundant higher up. Ferns are found abundantly above 1,300 ft. elevation such species as Doryopteris pedata, Polypodium lepidopteris, P. pectinatum, and P. squamatum being the most common. Such epiphytes as Peperomia galapazensis, and Tillandsia insularis are also found. The undergrowth, whieh is made up largely of Toumefortia strigosa, becomes thicker than lower down.

The rolling plateau, which extends from $1,400 \mathrm{ft}$. to the lase of the main erater at $2,200 \mathrm{ft}$. elevation, is covered with forests of Pisonia floribunda, Psidium galapageium, Scalesia pedunculata, and Zanthoxylum Fagara. The Scalesia trees are the most abundant in this region, and form true Scalesia forests, as on some of the other larger and higher islands of the group. The trees of Psidinm galapageium are smaller than at similar elevations on other islands where this species occurs. Bushes of Tommefortia strigosa continue into this region and such other bushes as Brachistus pubescens, Croton Scouleri var. grandifolius, Erigeron tenuifolius var. tomentosus. Phytolacea octandra, Psychotria rufipes, Tournefortia rufo-sericea, and Urera alceaefolia are commonly found, especially towards the upper part of this region. There are many open areas, in the derper valleys between the hills and eraters, which are covered with a heavy 
growth of Paspalum conjugatum. In his Voyage of the Beagle, Darwin mentions that he found beds of Cyperus, on the upper part of this island, in which there was a species of water rail. The Ornithologists of the expedition suceeded in eapturing several speeimens of this rather rare bird, but in each instance they were found to be hidden in the thick growth of Paspalum grass, no beds of Cyperus having been found.

The forest trees, and bushes are heavily covered with epiphytes around 2,200 ft. elcration and above. Ferns are common among these, Polypodium aureum, and. Nephrolepis pertinata being the most abundant. Other epiphyes worthy of mention are: Epidendrum spicatum, Lycopodium iaxiolium, and Peperomia galapagensis, besides mosses and lichens. There are many species of terrestrial ferns in shady places and on mo:st banks. The Sealesia forests extend nearly to the top of the main erater on the leeward side, but on the windward side, which is bathed almost constantly by the strong sontheast trade winds for sereral months of the year, the trees begin to thin out a short distanee above the base of the crater and there are none at the top, although Zanthoxylum persists here as small gnarled bushes. Bushes of Psychotria rufipes are very common on this side and around the top. There are many ferns around the top, among which is Henitelia multiflora, the only tree feru on the islands.

The top of this mountain was heavily covered with fog at the time it was visited so that no general survey of the surrounding region could be made. As near as could be determined the dry region extends to about an elevation of $1,300 \mathrm{ft}$. on this side while the transition region extends to possibly $2,000 \mathrm{ft}$. varying, however, at different places.

The steep sides of the mountain, above the lava fields on the south side of the island, are eovered with the usual species found in the transition regions, a condition which extends up to above $1,600 \mathrm{ft}$. elevation. There are many ravines extending dowu this side, which broaden out occasionally and enclose park-like areas. In most places these ravines are filled with bushes and trees. Fruticose lichens are very abundant upon the regetation here.

\section{JERVIS ISLAND.}

Jervis lies about four miles off the south shore of Iames Island. It is a small island, not over two miles in diameter, whieh rises to a height of $1,050 \mathrm{ft}$., in consequence of which the sides of 
the island are very steep. A pebble beach extends along a portion of the north side, near which there is a small salt water lake surrounded on the sides by a small area of level land. There are three peaks on the island which vary in height from 950-1,050 ft. The flat area near the shore is covered with dark red soil mixed with bits of lava, but the steep sides have very little soil on them, except in low places and in crevices of the lava. The sides in places are strewn with small lava boulders.

Low bushes of Cryptocarpus pyriformis grow along the beach, while around the lake there are small trees of Avicennia officinalis, and Laguneularia lacemosa. Tangled thickets of Disearia pauciflora with very long stiff spines, and bushes of Maytenus obovata occur just above the lake on the side next to the land. There are many small trees of Bursera graveolens, and Opuntia myriacantha scattered over the lower part of the island. The first of these species gradually disappears higher up, while the second becomes very much reduced in size, appearing at the top in a more or less decumbent form. The steep sides of the island are covered with bushes which consist chiefly of Croton Scouleri, and Waltheria reticulata. All of the vegetation, above an elevation of $450 \mathrm{ft}$, is heavily covered with fruticose lichen indicating a somewhat greater amount of moisture than lower down.

The vegetation has a decidedly stunted appearance around the summit, and with the exception of a single species of fern, Polypodium squamatum, all of the other plants are distinctly dryregion forms. There are no trees at the top, and the bushes which occur there, are usually low and more or less prostrate.

\section{Narborough Island.}

Narborough, the third largest island in the group, is situated just west of Albemarle Island from which it is separated by a shallow channel about two miles wide at its narrowest point. The northern end of the island is nearly opposite Tagus Cove on Albemarle Island. A large crater, probably over 5,000 ft. in height is situated somewhat north of the center, and there is a gradual slope upward from the shore to the base of it on all sides but the north. The outer walls of the crater rise abruptly on the north side, and are almost perpendicular in places. There is a broad flat plain of old lava at the base of the crater on this side. 
This island shows more evidence of recent rolcanic activity than any other island in the group. The sides are covered in most places with deposits of basaltic lava and volcanic cinder which are practically bare of vegetation in most places. There are, however, occasional islands of older lava, which were not covered by the more recent flows, on which there is a considerable amount of vegetation. Some of these islands are quite large. One was visited on the north side, and was found to extend from the base of the crater to the shore, while on the east and west sides of it there were extensive beds of volcanic cinder of more recent origin. The older lava was deeply stained through weathering. There were occasional lava tunnels in the older lava, the tops of which had fallen in in places leaving openings into long narrow caverns high enough in places for one to walk through them in comfort. There was but little soil on this part of the island in consequence of which the vegetation was very scanty.

The island was visited for botanical purposes on the north, and northeast sides. The shores are bordered by low cliffs, along the north side, which are almost perpendicular in most places. On this account landing is difficult and even dangerous except in calm weather. As there is no suitable anchorage on this side, we visited it in boats, and it was necessary for one member of the party to remain in the boat and keep it off shore, while the remainder of the party did their collecting. On this account our stay here was more limited than it would have otherwise been.

Botanical conditions were very discouraging. There are no trees of any kind on this part unless the few small Burseras which occur here, could be designated as such. Neither Cereus or Opuntia is to be found although they both occur on the south side of the island. There is a scattered growth of bushes consisting of: Castela galapageia, Cordia Hookeriana, Euphorbia diffusa, Lippia rosmarinifolia, Scalesia narbonensis, and Waltheria reticulata forma intermedia. Vines of Asclepias ancustissima, and Cissampelos Pareira were found to be growing on the bushes in places. Several species of grasses grow from the lava crevices among which are, Bouteloua pilosa, Cenchrus granularis, Eragrostis ciliaris, and Paspalum canescens. A single fern, Notholaena sulphurea, was found at an elevation of about $500 \mathrm{ft}$. 
The part of the island visited on the northeast side, is about opposite Tagus Cove. There is a small bay at this place around which there are small mangrove swamps, as there are at several other places along the east and south shores of the island. Botanical conditions were even more discouraging here than they were on the north side, as all of the country in this vicinity was found to be covered with beds of recent lava on which there was apparently no other vegetation than occasional specimens of Cereus nesioticus and Cyperus Mutisii.

Mr. Beck succeded in reaching the top of the mountain, when he visited the island from the south side somewhat earlier in the season. He reported it to be heavily covered with regetation, among which were ferus and other mesophytic plants. He also reported a heavy growth of tall grass around the top, which from his description, must have been Pennisetum exalatum. There are two lakes inside the crater which are probably 2,000 ft. or more below the rim. The inner walls were covered with recent lava.

\section{Seymour Islanis.}

The Seymour Islands, three in number, lie off the northeast corner of Indefatigable Island of which they probably formed a part some time in the past. The islands are all low and are separated from each other by relatively narrow and shallow channels. South Seymour, the only one of the three visited, is the largest and lies closest to Indefatigable from which it is separated by a channel about one half mile in width.

The shores of this island are steep and formed by low eliffs. except in two places on the west side, where there are sand beaches. One of these beaches borders a rather large bay which affords good anchorage for vessels. Back of this bay there is a flat sandy area of some extent, but otherwise the surface of the island is covered with large irregular boulders of lava in between which there is a scanty light red soil.

The densest vegetation on the island occurs on the sandy area mentioned above, where thickets of bushes made up of Cryptocarpus pyriformis, Discaria pauciflora, and Maytenus obovata are to be found. In front of these thiekets, there is a considerable area along the beach which is covered with Ammophila arenaria, the only place on the islands where this species has been found. The remainder of the island is covered with small 
Bursera trees, bushes of Castela galapageia, Gossypium barbadense, small specimens of Opuntia, Parkinsonia aeuleata, and Prosopis dulcis. Some of the Bursera trees are evidently B. malacophylla, an endemie speeies collected on the Seymour Isands some years ago by Snodgrass and Heller, but whether or not they were all of this species could not be determined as the Bursera trees were in the resting eondition both times this island was visited by our party. A few dried leaves was all that could be obtained of this species.

There is a small salt-water lake near the west side around which there are a few small trees of Avicennia offieinalis. Mangrove swamps are probably present along the shore of the channel separating the island from Indefatigable, but as they were only seen from a distance the extent and composition of them could not be determined. Goats have been introdueed upon this island during the past few years, by the inhabitants of one of the other islands. They manage to gain a miserable existenee from the seanty vegetation and render the island even more barren than it would otherwise be.

North Seymour is next in size to South Seymour. It is apparently eovered with a dense growth of Croton, and other bushes. The middle island is low and small. There were large red-colored patches of vegetation on it which had the appearance from a distance of being composed of Sesuvium Edmonstonei.

\section{TOWER ISLAND.}

This is one of the smaller islands which lies about twenty-eight miles east of Bindloe. The shores are bordered by cliffs about forty feet high on all sides exeept the south where there is a small bay and sand beaches. The island is only four miles in diameter and is low in altitude, the highest point on it not being over $200 \mathrm{ft}$. above sea level. There is a crater, nearly a half mile in diameter near the eenter, but which can not be seen from the shore or from the surrounding ocean as there is no rim projeeting above the surrounding country. There is a small saltwater lake at the bottom of this erater on the shore of which there is a grove of trees of Rhizophora Mangle. Small blowholes oceur at other places on the island.

Outside of the mangroves just mentioned, there are no other trees on the island except those of Bursera graveolens, which are 22-S. \& A. 
small and heavily covered with lichens. Low thickets of Opuntia Helleri oceur along the tops of the clifts and for some distance back from them, and (ereus nesiticus is to be found in several isolated spots on the island. The most common bushes are those of Cordia lutea, Croton Scouleri, Lantana peduneularis, and Waltheria reticulata forma Andersonii. A few grasses, sedges, and other herbaceous plants have been reported from this island, but as our party visited it during the dry season in September, none of these were found.

\section{WENMaN ISLAND.}

With the exception of Culpepper, Wenman is the most northern island of the group. It is nothing more than an immense rock, about a mile in diameter, which lies seventy six miles northwest of Abingdon Island. The main island is surrounded by perpendicular cliffs on all sides but the north where they are somewhat broken down so that a landing can be effected and the upper part reached. In many places the clifis are several hundred feet high, and some of then reach practically to the highest part which probably has an elevation of about $800 \mathrm{ft}$. There is a smaller island, to the north of the main one, and separated from it by a narrow channel. This, however, was not visited by our party. The channel between the islands is comparatively shallow and it is likely that an anchorage could be made here. It was not attempted by our party.

We were unable to remain on this island for more than a few hours in consequence of this the higher parts were not visited, botanical collecting being confined to a shelf about $250 \mathrm{ft}$. above sea level. The remainder of the island rises several hundred feet higher.

The only trees found on the island were those of Erythrina velutina, a small grove of which occurs on the northeast side. Bushes of Croton Scouleri var. brevifolius oceur in dense thickets and some of the specimens are several feet high approaching the size of small trees. Low thickets of Opuntia Helleri are to be found along the tops of the cliffs and hanging over the sides. Ipomoea Kinbergi occurs commonly on trees. Other plants found rather abundantly are: Scalesia Snodgrassi, and Telanthera Helleri var. obtusior. A few ferms were seen growing in inaccessable places on the sides of the cliffs. By shooting into a 
bunch of these enough material was brought down to show that Nephrolepis biserrata occurs here, but whether or not there are any other species of ferns can not be said. The small island, to the north of the main one, appeared to be covered with Croton, and other bushes. 
SOME OBSERVATIONS CONCERNING THE BOTANICAL CONDITIONS ON THE GALAPAGOS ISLANDS.

\section{INDEX}

\begin{tabular}{|c|c|}
\hline atroduction . & 272 \\
\hline Abingdon Island ... & 273 \\
\hline Albemarle Island ...... & 276 \\
\hline Barrington Island $\ldots \ldots \ldots \ldots \ldots$ & 292 \\
\hline Blndloe Island $\ldots \ldots \ldots \ldots \ldots$ & 294 \\
\hline 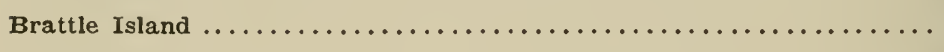 & 295 \\
\hline Charles Island $\ldots \ldots \ldots \ldots \ldots \ldots$ & 296 \\
\hline Chatham Island $\ldots \ldots \ldots \ldots \ldots \ldots \ldots \ldots \ldots \ldots \ldots \ldots \ldots \ldots \ldots \ldots$ & 301 \\
\hline Culpepper Island $\ldots \ldots \ldots \ldots$ & 308 \\
\hline 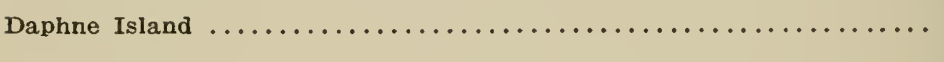 & 308 \\
\hline 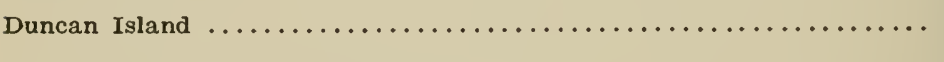 & 308 \\
\hline 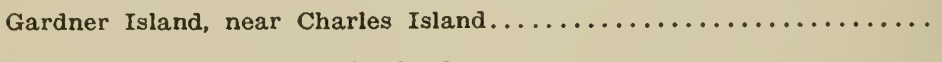 & 311 \\
\hline 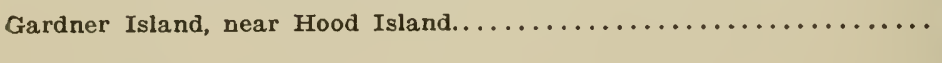 & 312 \\
\hline Hood Island $\ldots \ldots \ldots \ldots \ldots \ldots \ldots$ & 312 \\
\hline Indefatigable Island ... & 314 \\
\hline James Island $\ldots . .$. & 327 \\
\hline Jervis Island $\ldots \ldots \ldots \ldots \ldots$ & 333 \\
\hline Narborough Island...$\ldots \ldots$ & 334 \\
\hline 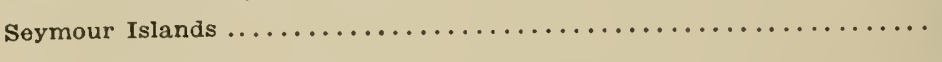 & 336 \\
\hline ower Island $\ldots \ldots \ldots \ldots \ldots \ldots \ldots \ldots \ldots \ldots \ldots \ldots$ & 337 \\
\hline enman Island & 338 \\
\hline
\end{tabular}


$x^{1}+2$

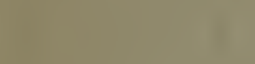

1.1.

$\cdot$

$\sqrt{2}$

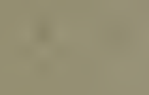

.

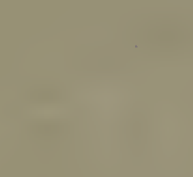

$=x$ 



QK 252.S71 Nork Botantcal Garden Library

Stewart, Alban/Some observations concern

|| || || || || | || || || | || ||| || || || || || ||

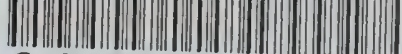

3 5185001647765 


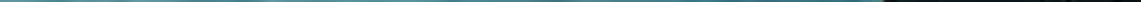

